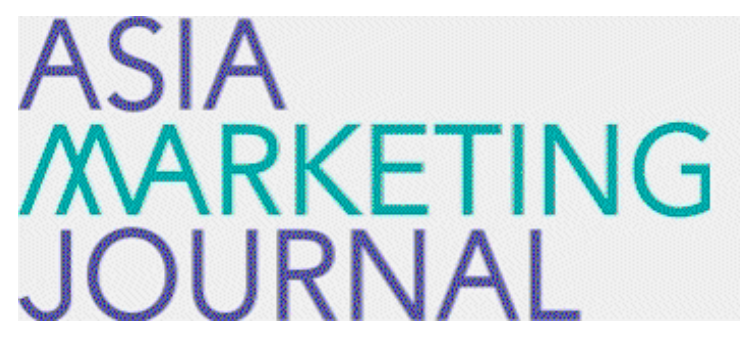

ASIA MARKETING JOURNAL

Volume 5 | Issue 1

Article 2

$3-25-2003$

\title{
지역정서소구메시지 유형별 소비자 설득효과에 관한 연구
}

윤룡 홯

Follow this and additional works at: https://amj.kma.re.kr/journal

Part of the Marketing Commons

\section{Recommended Citation}

홯, 윤룡 (2003) "지역정서소구메시지 유형별 소비자 설득효과에 관한 연구," Asia Marketing Journal: Vol. 5 : Iss. 1 , Article 2.

Available at: https://doi.org/10.53728/2765-6500.1100

This Article is brought to you for free and open access by Asia Marketing Journal. It has been accepted for inclusion in Asia Marketing Journal by an authorized editor of Asia Marketing Journal. 


\section{지역정서소구메시지 유형별 소비자 설득효과에 관한 연구*}

\section{The Effect of the Types of Local Emotion-Appealed Messages on the Consumer Persuasion}

황윤용(전북대학교 경영학부 강사)

yyhwang@business.chonbuk.ac.kr

본 연구는 최근 기업돌이 광고촉진의 한 수단으로서 많이 활용하고 있는 톡정 감정소구의 한 형태로서 지역정서를 이용한 광고의 설득효과를 탐색하기 위하여 지역정서소구메시지 유 형올 촉진형 메시지와 예방형 메시지로 구분하고, 이 메시지유형들의 설득효과에 대하여 소 비자의 지식수준과 자기지역중심성향(CLOCAL)이 어떻게 조절작용을 하는가를 탐색적으로 검 토하였다. 연구결과 지역소비자에 대한 지역정서소구광고의 메시지유형별 설득효과는 소비 자 개인특성의 조절변인으로서 지식수준과 자기지역중심성향 수준올 고려했을 경우, 촉진형 메시지와 예방형 메시지 모두에서 유의적인 차이를 발견할 수 있었다. 먼저. 소비자의 정보 처리능력과 관련하여 지식수준이 높은 집단에서는 촉진형 메시지가 더 설득적이었고, 지식 수준어 낮은 집단에서는 예방형 메시지가 더 설득적임을 발견하였다. 그러나 소비자의 자기 지역중심성향수준에 따라서는, 높은 수준의 집단에서는 예방형 메시지가, 낮은 수준의 집단 에서는 촉진형 메시지가 더 효과적인 것으로 나타났다. 끝으로 본 연구는 이와 같은 연구결 과를 바탕으로 지역정서소구광고의 메시지 톡성과 소비자특성에 따른 차별적인 지역정서소 구광고의 설계전략방안들올 제안하였다.

* 논문접수: 02,12 게재확정 : 03,02

본 논문에 유익한 조언을 주신 익명의 심사위원님들께 감사 드립니다. 


\section{1. 서론}

오늘날 소비자들은 수많은 광고홍수 속에서 소비생활을 영위하고 있다. 그리고 이러한 광고들의 흐름을 보면 기존의 상표속성에 대한 인지적 관점의 정보제시 형태에서 소비자의 감성적인 측면에 호소하는 광고들이 한층 더 증가하고 있다. 즉, 1980 년대 초까지만 해도 광고효과에 대한 소비자행동 연구나 광고메시지의 정보처리 메커니즘에 대하여 주로 인지적 반응을 중심으로 많은 연구가 수행되어 왔으나 근래에는 감정적 측면을 고려한 연구돌도 활발하게 진행되어 오고 있다(김완석 1991, 1993; 이학식 1991; 이학식, 정주훈 \& 이호배 1998; Batra and Ray 1986; Burke and Edell 1989). 이들은 Fishbein and Ajzen(1975)의 합리적 행동이론(theory of reasoned action), Greenwald(1968)의 인지반웅(cognitive response) 이론과 같이 기존의 정보처리론적 광고효과 이론들이 주로 언어적 메시지에 대한 인지적 반응을 중시하고, 소비자의 감정적 측면을 소홀히 다루고 있음을 지적하며, 소비자들이 기존의 심리학적 또는 정보처리적 관점의 주요한 가정이었던 합리적인 의사결정보다는 감정적 측면과 관련된 의사결정을 더 크게 하고 있음을 주장하였다. 이러한 현상을 반영하듯, 최근의 광고들은 상품자체의 정보를 제공하는 광고에서 각종 시청각요소를 통해 분위기와 이미지를 강조하는 감정적 측면의 소구내용을 많이 다루고 있다(김완석 1995).

그런데, 이성적인 소구인가 감정적인 소구인가에 관계없이 소비자가 광고정보를 이용할 때에 정보이용목적이 무엇인가에 따라서 선택하는 정보나 선호하는 정보가 달라질 수 있다. 특히 Aaker and Lee(2001)는 자기규제목표이론(self-regulatory goals theory)을 기반으로 이와 같은 정보이용목적을 추구목적과 회피목적으로 구분하고, 각각의 목적유형에 따라서 제시된 정보의 설 , 효과가 다르계 나타남을 입증하였다. 즉, 소비자들은 자신들의 목표를 지향하는데 있어서 즐거움을 추구하려 하고 고통을 회피하려 한다고 보면서, 개인적인 성취감이나 열망 둥 긍정적인 결과들을 달성하려고 하는 촉면과 책임감이나 의무감 등을 바탕으로 부정적인 결과들을 회피하려고 하는 측면이 있다고 보았다. Aaker and Lee(2001)는 전자의 경우에는 촉진형 메시지(promotion message)가 적합하고, 후자의 경우에는 예방형 메시지(prevention message)가 적합하다고 제안하였다. 따라서 이와 같온 맥락에서 비록 광고의 정보제시형태가 감성적 메시지들을 중심으로 소구된다고 할지라도, 소비자에게 감성적 정보들을 어떠한 형태로 설계해서 제시해야 하는가에 대한 문제의 검토가 필요하다. 본 연구는 이러한 관점에서 광고의 전달메시지 유형을 Aaker and Lee(2001)의 연구에서 활용되었던 두 가지 메시지 유형들을 도입하여, 제품자체의 기능이나 우수성 둥을 강조하는 촉진형 메시지와 초래되는 부정적 결과의 회피를 방지하기 위해 책임감이나 의무감 등에 호소하는 예방형 메시지로 구분하여 사용하고자 한다.

한편, 최근 지방화 시대와 더불어 제품의 개별적인 특성을 일반화시켜 표준화된 데시지를 전달하는 전국광고(national advertisement) 못지 않게, 특정 지역 소비자들의 욕구나 문화 또는 사회적 특성 등에 맞추어 광고를 하는 지역정서소구광고(local emotion-appealed advertisement) 도 매우 활발하게 수행되고 있다. 즉, “내고장 상품", “우리지역에 소재해 있는 기업들이 만든 상품", 또는 "내고장에서 만든 상품을 애용하는 것이 자금의 역외 유출을 막고 지역발전을 앞당긴다" 둥의 형태로 소비자들의 자기지역중심성향(consumer localism: $\mathrm{CLOCAL}$ )에 호소하는 광고들이 많이 등장하고 있다.

그러나 이처럼, 기업의 시장에 대한 접근노력이 차별화를 위해 갈수록 세분화, 개별화 되어가고 있지만 지금까지의 광고효과에 대한 연구들은 주로 전국광고를 대상으로 이루어져 
온 실정이다. 따라서 기존의 전국광고의 효과 못지 않게 특정 감정소구의 한 형태로서 지역정서소구에 대한 소비자들의 평가가 어떠한 가를 파악해 볼 필요가 있다. 아울러 이와 비숫한 유형으로서 그 동안의 선행연구들은 주로 톡정 국가를 중심으로 한 소비자의 자민족중심성향(consumer ethnocentrism)이 제조국에 의해 형성된 상표태도나 점포태도 둥에 어떻게 영향을 미치는가를 조사해 왔다(이동대 \& 신창훈 2001; Levine and Campbell 1972; Shimp and Sharma 1987). 그리고 이들의 연구결과들에서 소비자의 자민족중심성향이 상표태도나 점포태도를 조절하는 것으로 나타났다. 이와 같은 맥락에서 소비자의 자기지역중심성향도 지역정서소구메시지에 따른 광고효과에 영향을 미칠 것으로 기대할 수 있다.

또한, 설득정보에 대한 소비자들의 정보처리과정과 관련하여 많은 연구자들은 주의 (attention), 이해(comprehension), 설득(persuasion)과정에 대한 능력(ability)의 역할들에 많은 관심을 가겨왔다. 그 동안 능력변수로서 폭넓게 검토되어 온 변수로는 소비자 지식(consumer knowledge), 친숙성(familiarity), 이용반도(frequency of use) 둥이 처리된 정보의 양(Brucks 1985; Johnson and Russo 1984), 단서이용(Rao and Monroe 1988), 평가과정(Sujan 1985), 회상(Zinkhan and Muderrisoglu 1985), 정교화과정(Brucks 1985; Celsi and Olson 1988; Sujan 1985)에 영향을 미치는 것으로 알려져 왔다. 그리고 이와 관련된 연구돌의 공통된 점은 이러한 변수들이 소비자의 정보처리에 매우 중요한 영향올 미친다는 사실이다. 특히, 광고를 통한 소비자의 설득모델에서도 정보처리능력 변수로의 지식수준은 매우 중요한 의미를 가지고 있는 것으로 알려지고 있다(Petty and Cacioppo 1979; Petty, Cacioppo and Schumann 1983). 그러나 이러한 중요성에도 불구하고 기존에 주로 다루어 왔던 정보처리능력으로서의 지식수준에 대한 관점은 주로 인지적 측면의 소구내용을 중심으로 다루어져 왔고 상대적으로 감정적 측면의 내용에 대한 지식수준의 역할에 관한 연구들은 다소 미흡한 편이다 특히, 특정 감정소구의 한 형태인 지역정서소구광고에 대한 효과와 지식수준의 역할에 대한 연구는 거의 없는 실정이다.

따라서 본 연구는 특정 감정소구의 한 형태로서 지역정서소구메시지가 포함된 지역정서 소구광고의 설득효과(persuasion effects)를 탐색하기 위하여 지역정서소구메시지 유형을 촉진형 메시지와 예방형 메시지로 구분하고, 이 메시지유형들의 설득효과가 소비자의 지식수준과 자기지역중심성향수준에 따라 어떻게 달라지는가를 탐색해 보고자 한다.

\section{2. 이론적 배경 및 가설의 설정}

\section{1 광고소구로서의 지역정서소구}

소비자를 향해 기업의 마음올 전달하는 광고에 있어서 중요한 고려점 중의 하나는 "이 광고에서 무엇을 이야기할 것인가(what to say in advertising?)"의 내용올 결정하는 것이라 할 수 있다. 그리고 광고에서 무엇을 이야기 할 것인가가 결정되면, 그 다음으로 그 메시지를 어떻게 표현할 것인지 즉, 광고의 소구유형을 결정하여야 한다(안광호 \& 유창조 1998). 광고소구(advertising appeal)란 소비자들의 주의와 관심을 유발하거나 또는 제품, 서비스에 대한 소비자의 태도에 영향을 주기 위해 사용되는 방법을 말하는데, 크게 이성적 소구(rational appeals)와 감정적 소구(emotional appeal)로 나눌 수 있다. 
이성적 소구는 흔히 정보 제공적 소구(informational appeal)라고도 하는데 이는 소비자가 광고를 본 후에 제품구매의 장점을 평가할 수 있도록 하기 위하여 관련된 사실적 정보들을 명료하고 논리적인 방법으로 제시하는 것으로서 주로 로고스적 소구(logos appeal)형태를 말한다. 이러한 형태를 통하여 제품에 대한 정보를 얻음으로써 이성적인 소비자는 제품의 특성을 구별하여 구매의사결정을 내리게 된다. 그러나 때때로 소비자들이 이성적이지 못하고 정보를 구하려는 관심이 부족함에도 불구하고 소비자에게 왜 그 제품을 구매해야 하는가에 대한 이유를 논리적이고 사실적으로 제시하는 형태로써도 소비자에게 충분히 직접적이고 정보지향적인 영향력을 심어줄 수 있다. 이처럼 이성적으로 소구하는 광고는 소비자의 실용적, 기능적, 효용적 욕구에 초점을 맞추고 있다. 따라서 이성적으로 소구하는 광고는 제품이 가지고 있는 특정 속성이나 편익을 강조하여 소비자의 구매를 적극적으로 유도하고자 한다. 또한 기업입장에서는 정보제공적 측면에서 자사 제품 또는 서비스가 소비자들의 욕구를 충족시켜 줄 수 있는 특별한 효익올 가지고 있음을 확신시켜 주기도 한다.

감정적 소구는 이성적 소구와는 달리 소비자의 심리적·사회적 욕구에 초점을 맞춘 파토스적 소구(pathos appeal)형태의 광고인데, 오늘날 많은 광고들이 감정적 소구를 이용하여 소비자들의 본능적 욕구를 환기시키려 하고 있다. 감정적 소구를 하는 광고에서는 로맨스, 향수, 동정, 흥분, 기쁨, 두려움, 죄의식, 슬픔 둥 자기자신과 관련된 개인적 감정과 존경, 자아이미지 고취, 지위, 과시 둥 타인들과의 관계에서 비롯되는 심리상태인 사희지향적 감정 등의 온갖 긍정적 또는 부정적인 감정들을 이용하여 소구한다. 또한 감정적 소구는 소비자의 기억반응에 긍정적인 장기적 효과가 있으며 호의적인 판단반응을 일으킨다. 특히 Friestad and Thorson(1986)에 따르면 감정적 소구를 소비자가 경험할 수 있는 정감의 양을 조절하는 수단이라고 하였다. 이러한 접근법에 의하면, 정서적으로 환기되어 있는 동안에 경험한 일화적(espisodic) 사건은 그렇지 않은 경우보다 강한 기억흔적을 남기며, 이 기억흔적은 제품과 관련된 의미적(semantic) 기억흔적에 통합될 수 있으며, 이러한 효과는 고관여 상황하에서 발생할 가능성이 크다고 보고 있다.

한편, 이와 같은 감정적 소구의 한 형태로서 오늘날 지역정서소구광고(local emotionappealed advertisement)도 많이 등장하고 있다. 지역정서소구광고란 특정 지역의 문화, 사회, 소비자들의 욕구와 관련된 메시지들(예:「우리 지역상품들이 최고」, 「우리고장, 우리기업의 성장이 지역발전을 앞당긴다」, $r$ 여러분의 현명한 판단이 지역경제를 살립니다」, 「내고장 상품의 애용은 지역사랑의 시작입니다」, 「내고장 상품의 구매는 자금의 외부유출과 실업문제 둥을 막을 수 있습니다」, $「$ 향토사랑, 향토기업사랑」둥)을 통하여 소비자의 긍정 또는 부정적 감정을 자극함으로써 구매나 특정 행동을 유발하게 하려는 소구 형태를 말한다. 그리고 이러한 광고는 주로 제조업체에 의해 행해지는 전국광고와는 다르게 일정한 지역의 소매점이나 지역기업에 의해서 행해지는 특징이 있다(이두희 2000). 따라서 지역광고는 한 지역의 소매점 또는 지역기업이 광고주가 될 수 있으며, 전국적인 광고가 주로 광고주의 상표를 강조하는 측면이 강하지만, 지역광고는 몇 개의 상표나 또는 일부의 경쟁상표를 함께 광고하는 경향도 있다. 그러므로 지역광고는 전국광고에 비해 일반적으로 특정 지역의 점포나 기업에 대한 친근감 또는 애향심을 유발시켜 점포 애호도(store loyalty)를 형성하고, 이를 기반으로 구매행동을 유발함과 동시에 지역제품, 지역점포, 지역기업에 대해 마치 이웃과 같은 생각을 가지도록 소비자들에게 정감을 심어주는데 그 목적이 있다. 


\section{2 광고효과와 지역정서소구}

\section{2 .1 광고효과}

광고가 소비자에게 하나의 정보로 제시될 때 소비자는 이를 지각과정이나 또는 감정적 반웅에 의해 주어진 광고정보를 처리함으로쎠 매우 다양한 반응을 보이게 된다. 즉, 광고를 접한 소비자는 먼저 광고라는 자극에 주의를 기울이고 자신의 감각기관을 통해 그 자극을 받아들여 해석하는 과정을 거치게 된다. 이를 소비자의 지각(perception)과정이라 하는데, 소비자는 이 지각된 광고정보를 바탕으로 광고가 전달하는 상표의 속성을 인지적으로 평가하여 상표와 관련된 지식을 얻기도 하고, 또는 광고를 보며 느끼는 감정적 반응을 통하여 광고에 대한 태도를 형성하기도 한다. 그리고 이러한 과정을 거쳐서 형성된 긍정적인 상표태도는 소비자의 미래 구매의도에도 호의적인 영향을 미치는 것으로 알려지고 있다(이두희 2000).

많은 연구자들은 광고효과에 대한 이러한 현상을 보다 명확하게 밝히기 위하여 다양한 연구들을 수행하여 왔는데, 초기에는 주로 광고가 상표인지에 영향을 미치고, 상표인지는 다시 상표태도에 영향을 미친다는 광고정보처리과정에 대한 논의가 활발하게 수행되어 왔다(Greenwald 1968; Petty and Cacioppo 1979). 이를 인지적 관점에서 광고의 설득 메커니즘을 설명하려는 노력들이라 할 수 있는데, 이들에 따르면 소비자들은 광고가 제시하는 상표의 속성에 대한 정보롤 처리하고 난 후 상표에 대한 태도를 형성하고 이에 따라 행동의도를 형성하는 것으로 광고정보처리과정을 이해하고 있다. 반면에 80 년대 이후 감정반응에 읙한 상표태도형성 현상을 설명하려는 연구들이 활발하게 진행되면서 기존의 인지적 관점과 달리 소비자의 광고정보처리를 감정적 관점에서 이해하려는 노력이 다양하게 시도되었다(Batra and Ray 1986; Burke and Edell 1989). 이는 소비자가 인지적 사고과정이 없이도 광고에 대한 소비자의 단순한 느김만으로 상표에 대한 우호적인 태도를 형성할 수 있다는 는리로서 광고태도 이론을 기존의 인지적 관점에서 한충 더 강화시키는 계기가 되었다고 할 수 있다(Shimp 1981).

\section{2 .2 광고효과와 지역정서소구}

광고의 감정적 효과를 설명하는 대표적인 이론들로는 Zajonc(1968)의 단순노출(mere exposure)효과와 감정일치가설(affect congruency hypothesis) 둥을 제시할 수 있다. Zajonc의 단순노출효과는 소비자가 자극에 단순히 반복적으로 노출되는 것만으로도 그 자극에 대하여 긍정적인 태도를 갖게된다고 보는 견해이다. 즉, 자극에 대한 단순노출은 특별한 인지적 노력이 없이도 소비자의 태도가 형성된다고 보고 있다. 그리고 이처럼 반복노출이 효과를 가지게 되는 과정은 대상의 반복노출에 의한 친숙성 때문에 그 자극에 대한 긍정적인 감정을 경험하게 되는 것으로 알려지고 있다. 따라서 이를 광고효과와 관런하여 해석하면, 소비자는 광고상표에 대한 인지적인 정보처리와 관계없이 단순히 상표에 자주 노출함으로써 그 상표에 대한 친숙성이 높아지며, 친숙성이 높아질수록 그 상표에 대해 긍정적인 감정울 형성할 수 있으며, 이러한 긍정적인 감정이 그 상표에 대한 긍정적인 행동의 가능성을 높여준다고 볼 수 있다.

한편, 감정일치가설이란 입력정보의 처리나 저장, 정보의 인출, 대상의 특성에 대한 판단, 그리고 행동 등이 모두 유기체내의 감정과 일치하는 방향으로 이루어진다는 관점이다. 따라서 이 가설에 의하면 감정의 영향을 독자적인 것이 아니라 인지과정 즉, 정보의 저장과 
인출, 대상에 대한 평가와 판단 등에 대한 영향이라는 측면에서 설명된다. 만약 소비자가 긍정적인 감정상태에서 광고에 노출될 경우 광고상표에 관한 긍적적인 정보들이 더 잘 처리되며, 부정적인 감정상태에서는 부정적인 정보들이 더 잘 처리된다. 또한 이러한 감정은 기억내에서 감정과 일치하는 정보에 대한 접근가능성을 높임으로써 상표평가에 영향을 줄 수 있다고 보고 있다. 따라서 소비자가 긍정적인 감정올 야기하는 광고에 노출되는 동안 광고상표에 대한 긍정적인 판단을 형성하고 이를 토대로 향후 구매행동에 영향을 마치게 된다고 볼 수 있다. 그러므로 이와 같은 이론들을 종합해 불 때 소비자의 감정에 소구하는 광고는 소비자의 광고에 대한 태도 또는 상표에 대한 태도에 유의적인 영향을 줄 것으로 예상할 수 있다.

본 연구에서는 소비자에게 구매를 하거나 어떤 행동을 유발할 수 있게끔 지역단서들(local cues)을 활용하여 소비자의 긍정 또는 부정적 감정을 자극하려는 메시지형태를 지역정서소구광고라 하였다. 즉, 소비자들의 지역정서 또는 애향심 등에 어필하도록 메시지를 전달하여 그 메시지효과를 증폭시키려는 방법을 말한다. 따라서 소비자의 광고태도에 어필하기 위해 활용되는 지역정서소구단서들은 광고에서 제시한 상표태도에도 영향을 줄 것으로 기대할 수 있다. 즉, 지역정서소구에 노출됨으로써 소비자가 가지고 있는 지역정서의 긍정 또는 부정적 감정이 자극을 받게 되며, 이에 따라 이를 소구하는 광고나 상표에 긍정적인 태도를 형성하거나 또는 부정적인 태도를 형성할 것으로 예상된다.

\section{2 .3 광고효과와 지역정서소구메시지유형}

흔히 광고를 마케팅커뮤니케이션(marketing communication)이라고 표현한다. 이는 상황분석과 광고의 기본전략 그리고 매체전략 등이 마케팅전략을 중심으로 이루어지는 마케팅적 접근과 광고크리에이티브적 측면에서 다루어지는 커뮤니케이션적 접근이 모두 포함되어 있기 때문이다(서범석 1993), 따라서 지역정서소구광고에 대한 접근도 마케팅적 접근과 커뮤니케이션적 접근을 통합하여 살펴볼 수 있다.

일반적으로 사회문제를 설득의 도구로 사용하는 마케팅전략을 대의명분 마케팅(causerelated marketing)이라고 부른다. 이는 크고 작은 사회문제를 반영하여 소비자에게 대의명분을 공감하게 하고 집단주의적 의식을 고취시켜 제품판매로까지 연결지으려는 마케팅노력을 말한다. 따라서 마케팅적 측면에서 소비자의 지역정서에 소구하는 메시지는 지역산업의 위축이나 지역기업들의 발전을 앞당긴다는 점들을 부각하기 위해 활용되는 설득적 단서라 할 수 있다. 반면, 크리에이티브적 측면에서 지역정서소구광고는 소비자가 다른 지역제품보다 자기지역에서 생산된 제품을 사도록 소비자의 자기지역중심정서에 호소하는 하나의 소구방식이라 할 수 있다. 따라서 이는 주로 소비자의 감정에 호소함으로써 소비자에게 애향심을 유발하고 이에 따라 우리지역의 제품 또는 우리지역의 상표가 더 좋다는 이미지를 심어줌으로서 소비자를 설득하고 구매에 대한 타당성을 부여해주고 있다. 본 연구에서는 지역정서소구광고를 마케팅적 측면과 커무니케이션적 측면을 혼합한 개념으로 보고자 한다. 즉, 소비자에게 지역에서 생산되었다는 단서들과 함께 제품의 기능적인 우수성을 강조하여 소비자의 상표태도를 형성시키거나 또는 지역사회문제롤 설득적 도구로 사용하여 소비자의 자기지역중심성향에 호소함으로써 애향심을 유발한 후, 이를 토대로 제품에 호의적인 태도를 형성하고 더 나아가 구매의도를 형성하도록 하려는 것으로 보고자 한다.

그렇다면 이와 같은 지역정서소구광고들은 어떠한 것이 있을까? 아직까지 선행연구들은 
특정감정에 소구하는 한 형태로서 지역정서소구광고에 대한 효과 검토나 유형분류는 매우 미흡한 실정이다. 따라서 본 연구는 지역정서소구의 유형들을 살펴보기 위해 이를 보다 확장하여 소비자의 자민족 정서나 애국심 등에 호소하는 광고들을 토대로 이를 분류해 보고자 한다. 소비자의 자민족정서나 애국심 등에 호소하는 광고 역시 소비자의 정서변화에 초점을 맞추어 소비자로 하여금 제품에 대한 호의적인 태도나 구매를 유도하려는 방법이기 때문에 소비자의 자기지역중심성향 또는 애향심 둥을 자극하기 위해 사용되는 설득적 메시지와 유사한 맥락을 가진다고 할 수 있다. 선행연구들의 애국심호소광고의 분류 유형들을 보면 자긍심고취형과 애국심호소형 광고(정혜진 1996), 책임감과 산업퇴조 두려움 그리고 실업관련 두려움과 외제품을 구매함으로서 느끼는 괴의식 차원으로 형성된 애국심광고(한충민 1998), 제품의 우수성을 강조하는 기술우수성광고, 실업·산업퇴조의 두려움을 설명하는 경각형 광고, 단지 국산제품을 알리는 단순국산형 광고, 향수·정 둥 소비자의 감성에 호소하는 용기격려형 광고(김혜란 \& 송인덕 1998) 등으로 나누어 볼 수 있다. 따라서 이와 같은 애국심을 소구하는 광고형태를 토대로 소비자의 자기지역중심 성향에 소구하는 광고의 형태를 나누어 볼 수 있는데, 지역에서 생산된 제품의 우수성을 강조하는 기술우수성광고, 지역경제나 지역산업에 부정적 결과를 가져온다는 경각형 광고, 단순히 지역연고 둥을 내세우는 광고 둥으로 분류해 볼 수 있다.

특히, 오늘날 지역내에서 행해지고 있는 대부분의 광고형태들은 이 중에서도 우수성올 강조하여 긍정적 측면을 부각시키는 광고와 소비자가 이행하지 않음으로써 초래되는 부정적 측면을 부각시키는 광고로 나누어 살겨볼 수 있다. 즉, 대부분의 지역정서소구메시지의 유형들이 제품의 우수성을 강조하는 긍정적 측면의 촉진형 메시지(promotion message)와 지역제품올 애용하지 않음으로써 발생하는 부정적 측면들의 결과를 회피하기 위해 그 자극수단으로서 예방형 메시지(prevention message)들을 사용하고 있다. 그리고 그 전형적인 예들을 살펴보면 먼저, 긍정적 측면의 광고소구메시지들의 경우 " $\bigcirc \bigcirc$ 지역의 $\bigcirc \bigcirc$ 기업에서 만든 우수 제품”, “지역연고제품으로서 전국 품질경연대희에서 우수상올 수상한 제품”, "탁월한 성능을 가지고 있는 제품” 둥을 들 수 있고, 부정적 결과를 예방하기 위한 광고소구메시지들은 “이제 $\bigcirc \bigcirc$ 지역은 $\mathrm{O}$ 분야에서 더 이상 낙후될 수 없습니다", "당신의 현명한 판단은 지역경제를 살립니다", “지역사랑은 $\mathrm{O} O$ 제품사랑에서부터 시작됩니다" 둥을 열거해 볼 수 있다.

한편, 규제중심이론(regulatory focus theory)에 의하면 사람들은 자신들의 목표률 지향하는데 있어 즐거움은 추구하려 하고 고통은 회피하려 한다고 보고 있다(Higgins 1997). 즉, 사람들은 목표를 지향하는데 있어서 성취감이나 열망 둥 긍정적인 결과들을 얻으려고 하는 측면(promotion concept: 촉진개념)과 책입감이나 의무 둥을 바탕으로 부정적인 결과들을 희피하려 하는 측면(prevention concept: 예방개념)이 있다고 한다(Aaker and Lee 2001). 따라서 규제중심이론에 따르면, 촉진 중심에 입각한 소비자는 긍정적인 결과를 내기 위해 자신들의 행동을 규제하고, 반면에 예방중심에 입각한 소비자는 부정적인 결과를 내지 않으려고 자기 행동을 조절한다. 이러한 점온 소비자의 정보처리와 설득측면에 활용할 메시지의 유형별 전략을 수립하는 데에도 유용하게 이용할 수 있다. 즉, 광고률 통해 소비자률 설득할 수 있는 유형올 제품자체의 우수성을 강조하는 촉진지향형 광고와 초래되는 결과에 대한 위험을 회피하기 위해 의무감이나 책임감 둥을 강조하는 예방지향형 광고로 나누어 불 수 있다. 특히, 앞에서 논의한 애국심소구광고나 지역정서소구광고들도 대표적으로 이 두 가지 설득유형으로 나누어 볼 수 있다. 따라서 본 연구에서는 광고효과에 대한 지역정서소구의 
호과를 살펴보기 위하여 지역정서소구메시지의 유형을 지역에서 생산된 제품의 우수성을 강조하는 촉진형 메시지와 지역에서 생산된 제품들올 구매하지 않음으로서 야기하게 될 두려움이나 책임감 둥을 어필하는 예방형 메시지로 분류하고자 한다.

\section{3 지역정서소구메시지효과에 대한 지식수준의 역할}

Petty and Cacioppo(1981)의 정교화가능성 모델(elaboration likelihood model)에 의하면 소비자의 태도형성과정은 소비자가 정보를 처리하는 노력의 정도에 따라 다르다고 보고 있다. 즉, 소비자가 주어진 정보를 처리하는데 상당한 노력올 기울일 경우 이때의 태도형성은 설득메시지를 중심으로 인지적 사고를 하는 중심경로(central route)에 의해 이루어지고, 반면에 정보처리를 위해 그다지 노력을 기울이지 않올 경우 광고모델이나 분위기 등과 같은 주변경로(peripheral route)를 통해 이루어진다.

그런데 이 때 소비자가 광고정보를 처리하려는 노력의 정도(elaboration likelihood)는 소비자가 제품정보를 처리하려는 동기(motivation)와 능력(ability)에 의해 결정된다. 제품정보가 자신과 직접관련성(personal relevance)이 높은 경우, 그 제품을 처리하려는 동기가 높아진다. 또한 소비자가 제품에 대한 지식이 많고, 제품정보에 대한 이해력이 높을수록, 제품정보를 처리할 수 있는 능력이 커지게 되므로 정보처리노력의 정도가 높아지게 된다. 그러나 만약 소비자가 광고에서 주어진 커뮤니케이션 정보를 처리할 동기부여가 있더라도 실제로 그 정보와 관련된 인지구조가 명확하지 못하여 정보에 대한 진단성(diagnosticity) 판단능력이 미약하다면 인지적 반웅에 의한 정보처리보다는 주변단서를 통해서 커뮤니케이션 정보를 처리하기가 섭다. 그 이유는 $\mathrm{ELM}$ 에 따르면 동기와 능력은 각각 메시지 정교화(elaboration)를 위한 충분조건으로 간주되는 것이 아니라, 어느 하나라도 높지 않은 경우 주변단서롤 활용해서 평가 및 태도가 형성되는 필요조건에 불과하기 때문이다(Andrews 1988; Petty and Cacioppo 1986a). 따라서 제품에 대한 소비자의 정보처리능력은 광고효과에 매우 중요한 영향을 미친다고 할 수 있다.

일반적으로 소비자들의 문제 해결과정은 그들의 과거 경혐이나 제품에 대한 관여수준 또는 제품의 선택과정을 통하여 얻어진 제품에 대한 지식의 양에 의하여 매우 크게 영향을 받는다. 목표(goals), 선택대안(choice alternatives)과 선택기준(choice criteria)에 관하여 활성화된 지식은 효과적인 의사결정계힉을 이루기 위하여 소비자의 능력에 영향을 미친다. 소비자가 직면한 문제해결의 유형에 따라 지식의 역할을 살펴보면 목표에 대한 위계(goal hierarchy)에 있어서 낮은 지식올 가진 집단(초심자)은 단순한 위계로서 목표가 불명확하거나 잘 정의되어 있지 않으며 목표에 관하여 불확실성이 내재해 있다. 따라서 지식수준이 낮은 소비자들은 광고에서 제시되는 설득적 메시지에 대한 판단 능력이 매우 낮다고 할 수 있고, 이에 따라 자신의 판단에 대한 학신성이 지식수준이 높은 집단보다 상대적으로 낮기 때문에 타인 또는 외부정보에 의존하는 성향을 보이기 윕다. 이와 같은 의미에서 Alba and Hutchinson(1987)은 지식수준이 낮은 소비자들에게는 세밀한 정보처리를 기대하기가 어렵기 때문에 속성위주의 광고메시지보다는 효용중심의 메시지가 더 설득력이 있다고 제안하고 있다. 한편, Aaker and Lee(2001)에 의하면 상호의존적인 목표성향을 가지고 있는 소비자들은 집단에 대한 소속감, 의무 이행에 대한 명령 그리고 다른 사람에 대한 책임감 등을 가지고 있다고 한다. 그러므로 이러한 유형의 소비자들은 주로 자기목표를 달성하기 위하여 
위험회피(risk averse)관점에서 정보처리들을 하게 되고 집단내 다른 사람들과 함께 융화함으로써 자신의 자아목표를 달성하려 한다. 따라서 이들에게는 위험회피중심의 예방형(prevention) 광고소구메시지가 촉진형(promotion) 광고소구메시지보다 더 설득적일 것이라 판단된다.

반면에 지식이 높은 집단(전문가)은 명확하고 잘 정의된 하위목표를 가지고 있으며 복잡한 하위체계로서 구성되어 있다. 또한 고려대상(consideration set)과 선택기준에 대하여 지식이 높은 집단은 다수의 선택대안들을 고려하고, 선택기준으로서 제품과 관련된 구체적 속성정보나 또는 외부적 단서와 같은 관련 있는 제품지식의 폭넓은 범위들을 이용할 수 있다. 따라서 소비자들은 제품평가 능력이 증가할 수록 자신의 내적 단서들을 더 많이 사용할 수 있다. 이에 따라 이러한 성향의 소비자들은 광고에서 제시되는 설득적 메시지에 대한 판단능력이 매우 높다고 할 수 있다. 따라서 지식수준이 높은 소비자들은 자신의 판단에 대한 확신성이 높기 때문에 주로 자기자신 또는 내적 정보들올 더 많이 탐색하는 경향이 있다. 그러므로 이와 같은 소비자들은 지식수준이 낮은 사람들보다도 속성중심의 메시지가 더 설득적일 수 있다(Alba and Hutchinson 1987). 그리고 이러한 유형의 소비자들은 자신의 판단에 대한 확신성이 강하기 때문에 자신이 추구하는 목표과업을 독립적이고 자율적으로 수행하기가 쉅다. 즉, 자율적인 판단 또는 의사결정에 따른 성취감과 다른 사람들과 비교하여 더 나은 목표를 성춰하려는 열정 둥이 크다고 할 수 있다. Aaker and Lee(2001)는 이러한 유형의 소비자들에게는 설득정보의 제공시 예방형(즉, 위험회피형) 메시지보다는 촉진형 메시지가 더 설득적임을 주장하고 있다. 즉, 지식수준이 높은 소비자들은 상대적으로 낮은 소비자들에 비해 자신의 판단에 대한 주관성이 더 크기 때문에 목표성취적 관점에서 주어진 메시지들을 잘 구분하고 정리할 수 있으므로 촉진중심메시지가 더 중요하게 인식될 것으로 판단된다. 따라서 소비자들의 지역정서소구메시지유형별 광고설득의 영향력은 지식수준별로 다르다고 할 수 있는데, 지식수준이 높은 집단의 경우에는 예방형 메시지보다 촉진형 메시지가 더 설득적이고, 지식수준이 낮은 집단의 경우 촉진형 메시지보다 예방형 메시지가 더 설득적일 것으로 예상된다.

H1: 지역소비자에 대한 지역정서소구메시지의 유형별 설득효과는 소비자의 지식수준 에 따라 다를 것이다.

Hla: 소비자의 지식수준이 낮을 때, 지역정서소구메시지의 유형별 설득효과는 촉진형 메시지보다 예방형 메시지에서 더 클 것이다.

$\mathrm{Hlb}$ : 소비자의 지식수준이 높을 때, 지역정서소구메시지의 유형별 설득효과는 예방형 메시지보다 촉진형 메시지에서 더 클 것이다.

\section{4 지역정서소구메시지호과에 대한 자기지역중심성향수준의 역할}

일반적으로 소비자들은 자신이 속한 집단의 문화나 가치관올 중심으로 다른 집단의 문화와 가치관 둥을 이해하고 평가하며, 자신이 속한 문화와 동일하거나 유사한 집단의 정보에 대해서는 섭게 수용하고 우수한 것으로 보며 상이한 집단의 정보에 대해서는 열등한 것으로 보고 거부하는 경향이 있다(Shimp and Sharma 1987). Shimp and Sharma(1987)는 소비자들의 이러한 신념체계를 자민족중심주의(ethnocentrism)라 하였으며, 이는 소비자의 
애국심 개념과 관련성이 매우 큰 것으로 알려지고 있다. 자민족중심주의에 대해 국내에서도 많은 연구돌(이동대 \& 신창훈 2001; 최명규 1994)이 수행되어 왔는데, 이들의 연구결과는 자민족중심주의 경향이 높은 소비자들의 경우 자국의 문화나 시설 또는 제품 둥에 대해서 자민족중심주의 경향이 낮은 소비자들에 비해 더 호의적으로 평가하는 경향이 있으며, 반대로 타국제품에 대해서는 자민족중심주의 성향이 강한 소비자일수록 더 부정적으로 평가함을 보여주고 있다(Netemeyer, Durvasula and Lichtenstein 1991). 따라서 이와 같은 맥락에서 자기지역중심성향(consumer localism)이 높은 소비자들의 경우에는 특정 지역에 있는 문화나 기업 또는 제품에 대해서 보다 호의적인 태도를 가질 가능성이 높다. 그리고 이러한 소비자들은 지역정서소구단서로서 설득적 메시지가 제시될 경우 촉진형 메시지보다 예방형 메시지에서 설득효과가 더 클 것이라 예상된다. 왜냐하면 설득정보에 대한 자기규제이론에 따르면 촉진형 정보보다 예방형 정보들이 집단주의적 가치관을 가진 소비자들에게 더 설득적이기 때문이다. 따라서 자민족중심주의성향과 마찬가지로 자기지역중심성향도 지역내 집단주의적 가치관을 반영한다고 불 수 있으므로 개인 스스로의 가치관에 따라 설득효과가 높아지는 촉진형 메시지보다는 집단내 구성원으로서 올바르게 행동할 도덕적 의무감이나 책임감 등울 활용하여 집단주의적 행동을 야기하도록 하는 예방형 광고메시지가 더 큰 영향을 미칠 것으로 기대할 수 있다.

그러나 이러한 영향력이 소비자의 자기지역중심성향이 낮을 경우에는 반대의 결과가 예상된다. 즉, 이때에는 집단구성원으로서의 의무감보다는 자신의 개인적 가치관에 따라 설득정보를 판단하기 쉬우므로 예방형 광고메시지보다는 개인적 줄거움을 추구하는 촉진형 메시지에 더 큰 영향을 받으리라 예상할 수 있다. 따라서 다음과 같은 가설들을 설정할 수 있다.

H2: 지역소비자에 대한 지역정서소구메시지의 유형별 설득효과는 소비자의 자기지역 중심성향수준에 따라 다를 것이다.

H2a: 소비자의 자기지역중심성향수준이 낮을 매, 지역정서소구메시지의 유형별 설득 효과는 예방형 메시지보다 촉진형 메시지에서 더 클 것이다.

$\mathrm{H} 2 \mathrm{~b}$ : 소비자의 자기지역중심성향수준이 높을 때, 지역정서소구메시지의 유형별 설득 효과는 촉진형 메시지보다 예방형 메시지에서 더 클 것이다.

\section{3. 연구방법}

\section{1 피실험자}

본 연구는 실험적 방법(experimental method)에 의하여 자료를 수집하였는데, 피실험자들은 C지역 소재 학부 및 대학원생들로 구성되었다. 먼저, 1차 예비조사에서는 실험 자극물의 적절한 선정올 위하여 대학원 석 - 박사 과정생들을 위주로 15 명의 피실험자가 참여하였다. 그리고, 2 차 예비조사로서 광고의 지역정서소구정도를 조작검증하기 위해 지역소구와 비지역소구 형태로 나눈 광고들에 각각 학부생 50 명이 참여하여 검토되었으며, 최종적인 본 조사에 대해서는 지역정서소구의 메시지유형(촉진형 vs 예방형)들을 대상으로 각각 100 명씩 
총 200 명이 참여하였는데 남자가 108 명, 여자가 92 명이었고 평균연령은 23.32세 이었다.

\section{2 연구설계}

본 연구는 제 가설들을 검토하기 위하여 실험설계방법을 할용하였다. 즉, 가설 1(H1a, $\mathrm{H} 1 \mathrm{~b})$ 과 가설 2(H2a, H2b)를 살펴보기 위하여 지역정서소구광고의 메시지유형별 설득효과를 조절하는 변수로 소비자의 지식수준과 자기지역중심성향의 정도를 각각 고저로 나눈 후 이를 함께 고려하여 살펴보았다. 이를 위해 웅답자들은 촉진형 메시지 $(n=100)$ 와 예방형 메시지 $(n=100)$ 를 기준으로 지식수준과 자기지역중심성향수준의 고저에 따라 각 셀에 분류 되었다(표 1).

<표 1> 가설 1,2의 검중을 위한 실험집단별 노출광고

단위: 명

\begin{tabular}{|c|c|c|c|}
\hline \multicolumn{2}{|c|}{ 지역정서소구 매시지유형 } & 촉진형 메시지 & 예방형 메시지 \\
\hline \multirow{2}{*}{ 초심자 } & 낮은 자기지역중심성향 & \multirow{4}{*}{100} & \multirow{4}{*}{100} \\
\hline & 높은 자기지역중심성향 & & \\
\hline \multirow{2}{*}{ 전문가 } & 낮은 자기지역중심성향 & & \\
\hline & 높은 자기지역중심성향 & & \\
\hline
\end{tabular}

\section{3 상표 및 제품의 선정}

본 연구에 이용될 제품 및 상표를 선정하기 위하여 마케팅 또는 소비자행동을 수강해 본 경험이 있는 대학원생들을 대상으로 1차 예비조사가 실시되었다. 각 웅답자들에게는 지역정서 메시지를 잘 활용할 수 있으면서도 내적 타당성을 확보하기 위해 응답자가 대학생이라는 점을 고려하여 이들에게 가장 적절하게 어필할 수 있는 제품을 선정하도록 요구하였다. 그 결과 1차 사전조사에서는 개인용 컴퓨터(PC)와 우유가 제시되었다. 그리고 이 두 제품에 대하여 가상의 상표로서 PC는 '유니컴'올, 우유는 '초롱우유'라는 브랜드를 부여하고 다시 예비 테스트를 실시하였다. 제품에 가상의 상표를 부착한 이유는 실제상표률 제시해 줌으로서 올 수 있는 선입견에 의한 편의(bias)의 제거 및 기타 기존의 정보나 개인적인 경험에 기인한 외생변수들의 효과를 방지하기 위함이었다.

2차 논의 끝에 최종적으로 선정된 제품은 최근 각 지역별로 많이 이용되고 있는 컴퓨터(PC)가 선정되었다. 컴퓨터를 평가대상으로 고려한 이유는 컴퓨터가 비교적 복잡한 제품이면서도 대학생들에게 많은 관심을 유발할 수 있고, 또한 소비자들에게 PC 구매시 적합한 대안의 선정을 위해 보다 많은 전문지식을 요구하므로, 이에 따라 상대적으로 그 범위의 측정이 용이하다고 판단되었기 때문이다. 


\section{4 광고자극설계 및 평가절차}

\subsection{1 광고자극설계}

최종 본 조사에서 이용될 컴퓨터를 이용한 광고의 제작은 앞서 연구설계에서 기술한 2 가지 메시지 유형의 설계에 적합하도록 고안되었다. 먼저 예비조사로서 지역정서소구의 반영정도를 검토하기 위하여 지역정서소구내용이 포함된 광고와 지역정서소구내용이 포함되지 않은 두 가지 유형의 광고물이 제작되었다. 이때 광고제작은 2 단계의 작업을 거쳐 진행되었는데, 먼저 대상 컴퓨터의 시각적인 면과 웅답자들에게 약간의 인지적인 판단을 요하도록 약간의 속성단서(예: 사양대비 만족할 수 있는 가격, 이자부담이 전혀 없는 컴퓨터, 간편한구입절차/즉시설치, 컴퓨터 전문인력이 가까운 대리점, 다양한 구매특전)들이 제시되었다. 그리고 이 광고는 사전실험을 통하여 웅답자들이 쉽게 이해가능한지의 여부와 제시된 내용들의 적절성 여부를 판단하였다. 그런 다음 이러한 과정을 통하여 작성된 광고에 다시 지역정서소구 내용(예: 유니컴 $\mathrm{OO}$ 컴퓨터 탄생, $\mathrm{OO}$ 인을 위한 진정한 국민형 $\mathrm{PC}, \mathrm{O} \bigcirc \mathrm{O}$ 민께 특별 한정판매, 유니컴이 $\mathrm{O}$ 인에게 새로운 $\mathrm{PC}$ 규격을 제안합니다 등)을 포함시키고 모의 피험자들에개 지역정서소구정도를 응답하도록 요구하였다. 예비분석 결과 지역소구의 정도는 5.52(홍 7점)로서 매우 높게 표현되어 있음을 알 수 있었다. 그리고 이러한 절차를 거쳐 제작된 지역정서소구광고를 바탕으로 동일한 제품, 동일한 브랜드 네임, 동일한 레이아웃을 활용하고 지역단서의 광고문안만 달리하여(예: 유니컴 파워컴퓨터 탄생, 나만을 위한 진정한 국민형 $\mathrm{PC}$, 여러분께만 특별 한정판매, 유니컴이 여러분에게 새로운 $\mathrm{PC}$ 규격을 제안합니다 등) 비지역정서소구광고를 제작하였다. 그리고 이 두 유형의 광고물이 지역정서내용을 각각 얼마나 포함하고 있는가의 정도를 비교하기 위해 지역정서소구광고와 비지역정서소구광고간의 지역정서소구내용의 포함정도를 4개 문항[Cronbach's a(지역=.7798, 비지역=8993)]을 통하여 검토해 본 결과 지역정서소구광고 평균이 $4.80(\mathrm{n}=50)$, 비지역정서 소구광고 평균이 $2.04(\mathrm{n}=50)$ 로 통계적으로 유의적인 차이 $(\mathrm{t}=12.29, \quad \mathrm{p}<.01)$ 가 있음을 확인하였다.

한편, 위와 같은 예비조사를 바탕으로 본조사에 활용될 지역정서소구메시지 유형별 광고물의 제작도 예비조사와 유사한 방법으로 진행되었다. 먼저 예비조사에서 제작된 광고물 중 지역정서소구광고의 동일한 레이아웃을 배경으로 소구매시지만 다르게 하여 촉진형 메시지와 예방형 메시지를 삽입하였다. 이를 위해 대학원에 재학중인 피험자 10 명을 대상으로 각각의 개념올 설명한 후 평소 실제 보았던 메시지들을 참고로 하여 문항들을 기술하도록 요청하였다. 그리고 기술된 내용을 본 연구자와 마케팅박사 1 인이 이 내용을 각각 축약하여 정리한 후 이를 다시 상호 비교 정리함으로써 최종적인 촉진형 메시지와 예방형 메시지를 분류하였다(표 2). 이렇게 정리된 메시지는 다시 10 명의 피험자들에 의해 메시지의 촉진성 정도와 예방성 정도가 평가되었는데 그 차이는 각각 촉진형 메시지광고의 경우(촉진형=5.28 vs 예방형=3.10, t=4.48, p<.01), 예방형 메시지광고의 경우(촉진형=3.02 vs 예방형=5.58, t=-5.66, p<.01)로서 각각 적절한 메시지 유형임올 알 수 있었다. 끝으로 이렇게 검토된 메시지들은 본조사를 위해 각각 촉진형 지역정서소구광고와 예방형 지역정서 소구광고로 제작되었다. 
<표 2> 지역정서소구메시지 유형

\begin{tabular}{|c|c|}
\hline 촉진형 메시지 & 예방형 메시지 \\
\hline $\begin{array}{l}\text { 안녕하 } \\
\text { 당사는 이 지역 향토기업으로서 주로 도 } \\
\text { 전문적으로 생산해 왔습니다. 그 동안 여러 } \\
\text { 절약형 } \mathrm{PC} \text { 제품(인텔 펜티엄 } 4 \text { Proce }\end{array}$ & $\begin{array}{l}\text { 십니까? } \\
\text { 내에서 } \mathrm{PC} \text { 에 필요한 메모리와 모니터롤 } \\
\text { 분의 사랑을 계기로 } 2002 \text { 년부터는 중저가 } \\
\text { essor } 2 \mathrm{GHz} \text { )을 선보이게 되었습니다. }\end{array}$ \\
\hline 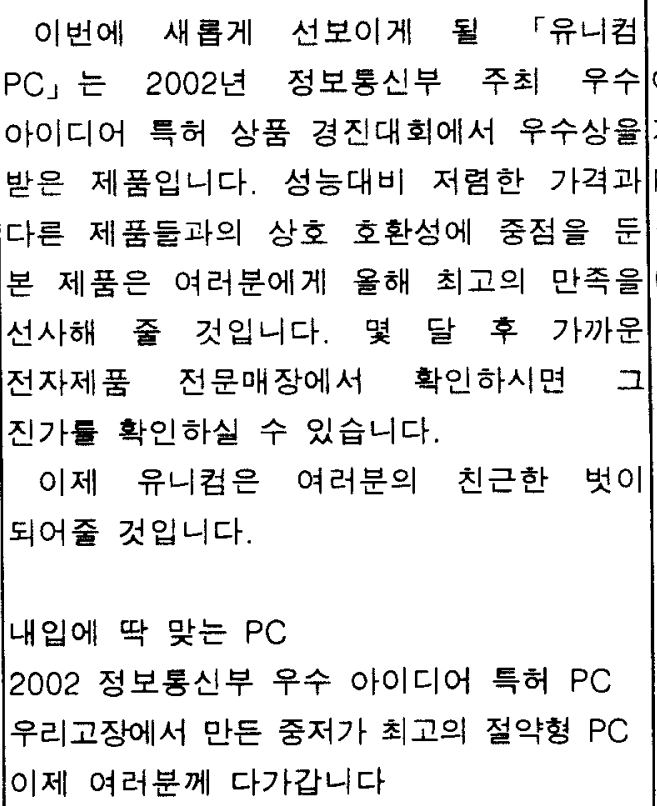 & $\begin{array}{l}\text { 그 동안 } \mathrm{O} O \text { 지역은 특히, 정보통신 분야 } \\
\text { 에서 많이 낙후되어 왔습니다. 이에 저희 } \\
\text { 기업온 도내에서는 최초로 중저가 보급형 } \\
\mathrm{PC} \text { 를 보급함으로써 작게는 저희 향토기업의 } \\
\text { 발전과 크게는 이 지역의 새로운 고용창출에 } \\
\text { 대한 기대와 지역경제발전에 기여하고자 } \\
\text { 합니다. 흔히 지역민의 무관심은 그 지역의 } \\
\text { 발전을 저해하고, 그 지역기업의 성장을 } \\
\text { 가로막는 장애요인으로 보고되고 있습니다. } \\
\text { 이제 이 지역의 사랑은 유니컴 사랑에서 } \\
\text { 부터 시작될 것입니다. } \\
\text { 내가 선택한 우리고장의 } \mathrm{PC} \\
\text { 유니컵 사랑은 지역사랑의 시작입니다. } \\
\text { 당신의 판단이 지역경제와 향토기업을 } \\
\text { 살립니다. }\end{array}$ \\
\hline
\end{tabular}

\section{4 .2 평가절차}

최종적으로 피실험자들에게 제시된 광고는 양질의 프린터를 활용하여 정교하게 인쇄함으로서 실제의 인쇄광고 못지 않은 효과를 보이도록 하였으며, 설문 웅답절차에 따라 광고에 노출될 때에는 컬러광고의 효과률 극대화하기 위하여 빔 프로젝터(beam projector)로 해당 광고물을 약 3 분간 제시하였으며, 이 때 피험자들에게는 촉진형 광고와 예방형 광고의 의미를 이해하도록 약간의 설명이 제시되었다.

설문 응답은 크게 두 가지 단계에 걸쳐 실시되었다. 피실험자돌에게는 먼저 자극물의 광고노출로 인한 웅답상의 오류를 방지하기 위하여, 광고가 제시되기 전에 평소 본인이 가지고 있는 컴퓨터에 관한 지식수준과 자기지역중심성향의 정도를 묻는 문항들이 제시되었다. 각 문항들에 대한 웅답을 완료한 후 이들에게 약 3 분 정도 지역정서소구가 반영된 최종 광고물을 보도록 하였다. 그런 다음 최종적으로 응답자들에게 제시된 광고물의 메시지에 대한 설득효과 문항들을 평가하도록 하였다. 끝으로 본 실헙의 조작검증을 위하여 $\mathrm{PC}$ 에 대한 개인적인 관여도를 묻는 문항과 함께, 촉진성향과 예방성향이 얼마나 포함되어 
있는가를 웅답하도록 요구하였다. 그리고 마지막으로 간단한 인구통계변수들에 대한 질문이 제시되었다. 설문에 대한 피실험자들의 정확한 응답을 유도하기 위하여 응답자들에게는 추첨을 통한 교내식권제공올 사전에 고지하고, 웅답 후 설문을 다시 한번 검토하게 한 후 현장 추첨을 통하여 교내 식권을 제공하였다.

\section{5 변수의 축정}

\subsection{1 설득효과}

설득(persuasion)이란 소비자의 태도와 행동에 영향을 미치기 위한 기업의 마케팅노력이라 할 수 있다(안광호 \& 유창조 1998). 즉, 마케터는 그 노력의 일환으로서 설득적인 광고메시지를 할용하여 소비자들이 자사제품에 대하여 호의적인 상표태도나 구매의도 등을 형성할 수 있도록 잘 유도해야만 한다. 이와 같은 맥락에서 본 연구에서는 "설득효과를 기업이 자사제품에 호의적인 상표태도나 구매의도 둥을 형성할 수 있도록 메시지를 제공했을 때, 기업이 의도한 대로 소비자가 그 메시지에 대한 수용태도를 보이거나 또는 소구메시지의 대상제품에 대하여 호의적인 태도나 구매의도 등의 형성에 기여할 것이라고 지각하는 정도"로서 정의하고자 한다.

이를 바탕으로 본 연구에서는 지역정서소구메시지의 설득효과를 검토하기 위하여 Aaker and Lee(2001)에서 활용되었던 설득효과의 측정문항들을 활용하여 광고메시지정보의 이용정도와 광고메시지에 따른 구매의향의 정도를 “전혀 그렇지 않다/매우 그렇다"의 7점 척도로 측정하였다[예: '내가 만약 유니컴을 구매하게 된다면 위와 같은 광고메시지들은 나의 구매의사결정에 좋은 참고가 될 것이다', '나는 평소 위와 같은 광고메시지들을 선호하는 편이다', '만약 구매를 고려할 때 위와 같은 광고메시지들이 나에게 제시된다면 내 판단에 적극적으로 활용하고 싶다', '나는 위와 같은 광고메시지들에 호감이 간다', '이 광고메시지는 내가 유니컴을 평가하는데 매우 효과적인 정보라고 생각한다', '이 광고메시지는 내가 유니컴을 구매하고자 할 때 매우 효과적인 정보라고 생각한다', '이 광고메시지를 읽고 나는 유니컴을 구매해보고 싶다는 생각이 들었다' (부록참조)].

\section{5 .2 지식수준}

본 연구에서는 정보처리능력 요소로서 그 동안 매우 많은 연구가 수행되어 왔던 사전지식(prior knowledge)을 지식수준 변수로서 활용하였다. 그리고 사전지식을 측정하는 변수로는 선행연구들(Alba and Hutchinson 1987; Brucks 1986; Park, Mothersbaugh and Feick 1994; Rao and Sieben 1992)에서 주로 활용되었던 객관적 지식(objective knowledge)과 주관적 지식(subjective knowledge)으로 분류하여 측정하였다. 소비자의 사전지식 중 객관적 지식은 전문지식 또는 제품과 관련된 업무를 수행할 수 있는 능력과 매우 밀접하게 관련되어 있다. 본 연구에서는 선행연구들올 토대로 개인용 컴퓨터에 관한 객관적 지식수준을 15 개 문항으로 측정하였다[예: '나는 컴퓨터를 구매한 적이 있다', '컴퓨터 범죄를 예방하기 위해서는 한 번 설정한 패스워드는 가급적 변경하지 않는다', '1GB는 $1024 \mathrm{~KB}$ 이다', 'Rom은 데이터를 읽고 쓸 수 있으며, 전원공급이 중단되면 데이터가 지워진다' 등(부록참조)]. 그리고 이러한 각각의 객관적 지식의 문항들은 정답올 기준으로 합산 처리되어 단일항목으로 이용되었다. 
또한 주관적 지식은 소비자가 정보탐색을 포함하여 제품과 관련된 업무를 잘 수행할 수 있는 자신감을 의미한다(Duncan and Olshavsky 1982; Park and Lessig 1981). 본 연구에서는 주관적 지식수준의 측정변수로 Brucks(1985), Park et al.(1994), 이학식과 김종성(1999)의 연구에서 활용된 문항들올 토대로 개인적으로 컴퓨터에 대해 잘 알고 있다고 느끼는 정도, 다른 동료에 비해 특정 제품울 잘 알고 있다고 지각하는 정도, 그리고 그 제품에 친숙한 정도를 “전혀 그렇지 않다/매우 그렇다”의 7점 척도로 측정하였다.

\section{5 .3 자기지역중심성향}

본 연구에서는 소비자의 자기지역중심성향(consumer localism: CLOCAL)을 특정 지역의 문화나 지역사회의 특성 또는 지역 소비자돌의 욕구와 관련되어 개별 소비자들이 가지고 있는 심리적 각성상태로 정의하고자 한다. 지금까지의 지역정서와 관련된 연구들은 주로 국가별 또는 동양과 서양이라는 매우 포괄적인 개념에서 연구되어 왔으나 한 국가내 특정 지역의 정서가 소비자의 구매의사결정이나 상표태도에 미치는 연구는 매우 미홉한 실정이다. 따라서 본 연구에서는 기존의 자민족 정서(CETSCALE)와 관련된 연구들(Klein, Ettenson and Morris 1998; Shimp and Sharma 1987)을 바탕으로 이를 본 논문의 지역정서소구에 맞게 수정하여 활용하였다. 그리고 개발된 문항들은 3 차례의 사전조사를 통해 문항이해도 및 각 문항들의 내적 일관성여부 등을 태스트하였다. 그리고 최종 조사에 활용된 문항들은 총 10 개로서 '전혀 그렇지 않다/매우 그렇다'의 7점 척도로서 측정되었다[예: '나는 이 지역에서 생산된 제품을 다른 지역에서 생산된 제품보다 더 좋아한다', ' $\mathrm{OO}$ 인은 항상 $\mathrm{OO}$ 지역에서 생산된 제품을 구매해 주어야 한다', '가급적 내가 원하는 제품이 $\mathrm{OO}$ 지역에서 생산할 수 없을 때에만 다른 지역의 제품을 구매해 주어야 한다', 'OO지역에서 생산된 제품을 구매하는 것이 지역기업을 살리는 길이다' 둥(부록참조)].

\section{4. 분석결과}

\section{1 실험조작의 학인}

본 연구에서는 광고의 지역정서소구메시지의 유형이 피헙자들에게 제시된 광고물을 통해 조작되었으며, 소비자의 지식수준과 자기지역중심성향은 수집된 자료들의 중위수(median)를 기준으로 분류하여 조작되었다. 본 연구의 제 가설들의 검토에 앞서, 각 메시지유형들의 조작이 타당하게 인식되었는지를 검증하기 위하여 각각 5 개 문항들에 웅답하게 하였다. 이들 문항들의 Cronbach's $a$ 는 촉진형 광고(.8778), 예방형 광고(.9017)로서 Nunnally(1978)의 권고치인 .7 을 상희하는 것으로 나타넜다. 그리고 각 소구내용별로 5 개 항목 각각의 평균점수의 비교에서는 촉진형 광고의 경우 촉진성향의 정도가 (촉진형 $=4.29$ vs 예방형 $=3.47$, $\mathrm{t}=4.39, \mathrm{p}<.01$ ) 이었고 예방형 광고의 경우 예방성향의 정도가 (촉진형=2.74 vs 예방형=5.41, $\mathrm{t}=-19.43, \mathrm{p}<.01)$ 로서 통계적으로 유의적인 차이를 보였다. 아울러 실험설계된 피혐자집단들내에 평가대상으로 선정된 컴퓨터에 대한 관여도는 촉진형 광고와 예방형 광고(5.88 vs 5.79, p>.10)로서 각각 비유의적인 것으로 나타나 응답자들간예 제품에 대한 관여의 편차는 없는 것으로 나타났다. 끝으로 설문응답자들의 설문응답에 대한 관심정도는 전체 평균(8.84, 10 점 만점)으로서 비교적 피험자들의 설문에 대한 관여의 정도가 매우 
높았음을 알 수 있었다. 따라서 본 연구의 실험조작은 적절하게 이루어졌음을 확인하였다.

\section{2 신뢰성과 타당성분석}

본 연구에서 활용된 측정변수들의 내적 일관성(internal consistency)과 수렴 타당성 (convergent validity)을 검토하기 위하여 각 요인별 측정항목들의 신뢰도 (reliability) 및 확인적 요인분석(confirmatory factor analysis)을 실시하였다. 그리고 이와 같은 분석과정을 거쳐 최종적으로 분석에 활용된 제 변수들은 <표 3>과 같다.

<표 3> 측정변수의 신뢰성 및 타당성

\begin{tabular}{|c|c|c|c|c|c|c|c|}
\hline \multicolumn{2}{|c|}{ 구성 개념a } & \multicolumn{3}{|c|}{ 요인적재량b } & \multirow{2}{*}{ E. $V^{c}$} & \multirow{2}{*}{$\begin{array}{l}\text { 분산의 } \\
\text { 설명력 }\end{array}$} & \multirow{2}{*}{$\begin{array}{c}\text { 신뢰계수 } \\
\text { (a) }\end{array}$} \\
\hline & & $\mathrm{F} 1$ & $\mathrm{~F} 2$ & F3 & & & \\
\hline $\begin{array}{l}\text { 설득 } \\
\text { 효과 }\end{array}$ & $\begin{array}{l}\text { PE1 } \\
\text { PE2 } \\
\text { PE3 } \\
\text { PE4 } \\
\text { PE5 } \\
\text { PE6 } \\
\text { PE7 }\end{array}$ & $\begin{array}{l}.939 \\
.933 \\
.929 \\
.928 \\
.926 \\
.911 \\
.856\end{array}$ & & & 5.960 & 29.802 & .9693 \\
\hline $\begin{array}{l}\text { 지식 } \\
\text { 수준 }\end{array}$ & $\begin{array}{l}\text { SK1 } \\
\text { SK2 } \\
\text { SK3 }\end{array}$ & & $\begin{array}{l}.931 \\
.916 \\
.867\end{array}$ & & 2.479 & 12.395 & .8907 \\
\hline $\begin{array}{l}\text { 자기 } \\
\text { 지역 } \\
\text { 중심 } \\
\text { 성향 }\end{array}$ & $\begin{array}{l}\text { CL1 } \\
\text { CL2 } \\
\text { CL3 } \\
\text { CL4 } \\
\text { CL5 } \\
\text { CL6 } \\
\text { CL7 } \\
\text { CL8 } \\
\text { CL9 } \\
\text { CL10 }\end{array}$ & & & $\begin{array}{l}.778 \\
.777 \\
.725 \\
.725 \\
.683 \\
.678 \\
.664 \\
.647 \\
.606 \\
.592\end{array}$ & 4.783 & 23.914 & .8750 \\
\hline
\end{tabular}

<표 3>의 신뢰성 분석 결과 Cronbach's alpha값은 설득효과(.9693), 지식수준(.8907), 자기지역중심성향(.8750)으로 나타나 각 측정문항들간에 내적 일관성이 있음을 확인하였다. 또한 요인분석 결과도 각 측정문항들이 해당 요인에 유의미하게 적재되었고, 각 구성개념에 대한 측정 문항들의 요인 적재량도 .59 이상을 확보함으로서 측정항목들간의 판별타당성 및 수렴 타당성을 확인하였다(임종원 1996).

\section{3 연구가설의 검증}

\subsection{1 가설 1 의 검중}

가설 1(H1)에서는 지역소비자에 대한 지역정서소구메시지의 유형별 설득효과는 소비자의 지식수준에 따라 조절될 것이라고 보았다. 즉, 소비자의 지식수준이 낮을 경우 지역정서소구 
메시지의 유형별 설득효과는 촉진형 메시지보다 예방형 메시지에서 더 크고, 반대로 소비자의 지식수준이 높을 경우 지역정서소구메시지의 유형별 설득효과는 예방형 메시지보다 촉진형 메시지에서 더 클 것으로 예상하였다.

본 연구에서는 이들올 검토하기에 앞서 소비자의 지식수준을 중위수(median=20, 총 36점)를 기준으로 점수가 낮은 집단은 지식수준이 낮은 초심자 집단(low knowledge group $\left.\mathrm{K}_{98}=14.74\right)$ 으로, 점수가 높은 집단은 지식수준이 높은 전문가 집단(high knowledge group $\mathrm{K}_{102}=24.54$ )으로 분류하였다. 그리고 이들 각 집단간 지식수준의 차이는 <표 $4>$ 에 제시된 바와 같이 유의적인 것으로 나타났다.

<표 4> 소비자의 지식수준에 대한 차이분석

\begin{tabular}{|c|c|c|c|c|c|}
\hline 수준구분요인 & $\begin{array}{c}\text { 자숭합 } \\
\text { (SS) }\end{array}$ & $\begin{array}{c}\text { df } \\
(n=200)\end{array}$ & $\begin{array}{c}\text { 평균자승 } \\
\text { (MS) }\end{array}$ & $\mathrm{F}$ 값 & $P$ 값 \\
\hline 집단간 분산 & 4804.510 & 1 & 4804.510 & 363.582 & $.000^{* * *}$ \\
\hline 집단내 분산 & 2616.445 & 198 & 13.214 & & \\
\hline 합계 & 7420.955 & 199 & & & \\
\hline
\end{tabular}

앞에서 구분된 두 지식집단을 대상으로 지역정서소구메시지 유형들(촉진형 vs 예방형) 간에 차이가 있는지를 검토해 본 결과는 <표 5><표 6><그림 1>과 같다.

<표 5> 소비자의 지식수준별 지역정서소구메시지 유형들의 설독효과

\begin{tabular}{|c|c|c|c|}
\hline & & \multicolumn{2}{|c|}{ 지역정서소구메시지 유형 } \\
\hline & & 촉진형 지역정서소구메시지 & 예방형 지역정서소구메시지 \\
\hline \multirow{2}{*}{ 지식수준 } & 초심자 & $2.92(52)^{\mathrm{a}}$ & $4.05(46)$ \\
\hline & 전문가 & $3.98(48)$ & $2.51(54)$ \\
\hline
\end{tabular}

a: 각 조건에서의 설득효과 평균치, ()는 각 샐의 빈도

<표 6> 소비자의 지식수준 집단별 지역정서소구메시지 유형들의 설득효과 차이분석

\begin{tabular}{|c|c|c|c|c|c|c|}
\hline & 수준구분요인 & $\begin{array}{c}\text { 자숭합 } \\
\text { (SS) }\end{array}$ & $\begin{array}{c}d f^{2} \\
(n 1=98) \\
(n 2=102)\end{array}$ & $\begin{array}{c}\text { 평균자숭 } \\
\text { (MS) }\end{array}$ & $\mathrm{F}$ 값 & $\mathbf{P}$ 값 $^{b}$ \\
\hline \multirow{3}{*}{$\begin{array}{l}\text { 초 } \\
\text { 심 } \\
\text { 자 }\end{array}$} & 집단간 분산 & 31.112 & 1 & 31.112 & 12.629 & $.001^{* * *}$ \\
\hline & 집단내 분산 & 236.506 & 96 & 2.464 & & \\
\hline & 합계 & 267.618 & 97 & & & \\
\hline \multirow{3}{*}{$\begin{array}{l}\text { 전 } \\
\text { 문 } \\
\text { 가 }\end{array}$} & 집단간 분산 & 55.227 & 1 & 55.227 & 26.519 & $.000^{* * *}$ \\
\hline & 집단내 분산 & 208.257 & 100 & 2.083 & & \\
\hline & 합계 & 264.484 & 101 & & & \\
\hline
\end{tabular}

$\mathrm{a}: \mathrm{nl}=$ 초심자 집단, $\mathrm{n} 2=$ 전문가 집단

b: *** p $<.01$ 
<그림 1> 소비자의 지식수준에 따른 지역정서소구메시지

유형별 설득효과

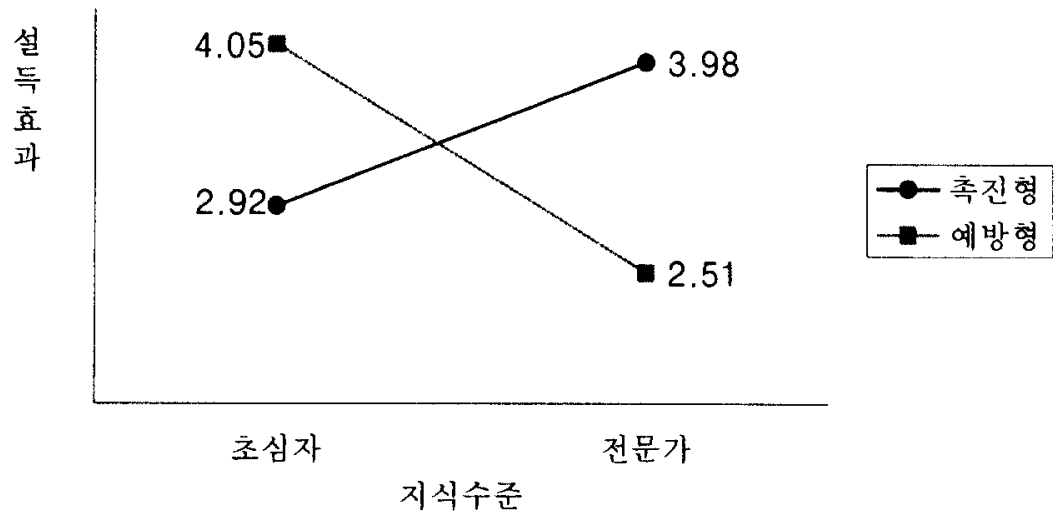

<표 6>과 <그림 1>의 분석결과에서 알 수 있듯이 소비자의 지식수준이 낮은 집 단에서는 촉진형 메시지 $(m e a n=2.92)$ 보다 예방형 메시지 $(m e a n=4.05)$ 가 더 설득적 효과가 있었고, 반대로 지식수준이 높은 집단에서는 예방형 메시지 $(m e a n=2.51)$ 보다는 촉진형 메시지 $(\mathrm{mean}=3.98)$ 의 설득효과가 더 큼을 알 수 있었다 $(\mathrm{p}<.01)$. 이는 동일한 지역정서소구 광고라 할지라도 메시지의 형태와 소비자의 지식수준에 따라 광고에 대한 설득효과가 달라질 수 있음을 의미한다. 즉, 지식수준이 낮은 소비자들은 상표평가에 대한 세밀한 정보처리의 어려움으로 인하여 자기확신성이 낮기 때문에 상대적으로 높은 지식집단에 비하여 타인의존적이거나 또는 집단에 대한 상호의 존적 성향을 보이기가 쉅다. 따라서 이들에게는 다른 대상 또는 다른 집단들로부터의 자기자신에 대한 책임감 또는 의무감 둥에 소구하는 예방형 메시지가 더 설득적임을 확인시켜 주고 있다.

그러나 지식수준이 높은 소비자들은 상표평가에 대한 세밀한 정보처리가 가능하기 때문에 주로 과업문제의 해결에 있어 자신의 판단에 대한 자기확신성수준이 상대적으로 더 높다. 따라서 이돌에게는 자율적 판단에 따른 의사결정이 이루어질 수 있도록 지역제품으로서 제품의 기능적 우수성들올 강조하는 촉진형 메시지가 더 설독적임을 시사해주고 있다. 결과적으로 가설 1 은 지지됨을 확인하였다.

\subsection{2 가설 2 의 검증}

가설 2(H2)에서는 지역소비자에 대한 지역정서소구메시지의 유형별 설득효과는 소비자의 자기지역중심성향수준에 따라 조절될 것이라고 보았다. 즉, 소비자의 자기지역중심성향 수준이 낮올 경우 지역정서소구메시지의 유형별 설득효과는 예방형 메시지보다 촉진형 메시지에서 더 크고, 반대로 소비자의 자기지역중심성향수준이 높을 경우 지역정서소구 메시지의 유형별 설득효과는 촉진형 메시지보다 예방형 메시지에서 더 클 것으로 예상하였다.

가설 1 과 마찬가지로 가설 2 를 검토하기에 앞서 소비자의 자기지역중심성향수준을 중위수(median $=40$, 충 70 점)를 기준으로 점수가 낮은 집단은 자기지역중심성향수준이 낮은 
집단(low consumer localism group $\mathrm{L}_{97}=31.67$ )으로, 점수가 높은 집단은 자기지역중심성향수준이 높은 집단(high consumer localism group $\mathrm{L}_{103}=47.09$ )으로 분류하였다. 그리고 이돌 각 집단간 자기지역중심성향의 수준 차이는 <표 7>에 제시된 바와 같이 유의적인 것으로 나타났다.

<표 7> 소비자의 자기지역중심성향수준에 대한 차이분석

\begin{tabular}{|c|c|c|c|c|c|}
\hline 수준구분요인 & $\begin{array}{c}\text { 자승합 } \\
\text { (SS) }\end{array}$ & $\begin{array}{c}\text { df } \\
(n=200)\end{array}$ & $\begin{array}{c}\text { 평균자숭 } \\
\text { (MS) }\end{array}$ & $\mathrm{F}$ 값 & $P$ 값 $^{2}$ \\
\hline 집단간 분산 & 11873.923 & 1 & 11873.923 & 288.129 & $.000^{* * *}$ \\
\hline 집단내 분산 & 8159.657 & 198 & 41.210 & & \\
\hline 합계 & 20033.580 & 199 & & & \\
\hline
\end{tabular}

앞에서 구분된 두 집단을 대상으로 지역정서소구메시지 유형들(촉진형 vs 예방형) 간에 차이가 있는지를 검토해 본 결과는 <표 8><표 9><그림 2>와 같다.

<표 8> 소비자의 자기지역중심성향수준별 지역정서소구메시지 유형들의 설득효과 지역정서소구메시지 유형

촉진형 지역정서소구메시지 예방형 지역정서소구메시지

\begin{tabular}{cccc}
\hline \hline 자기지역 & 낮은 수준 & $3.87(50)^{2}$ & $2.43(47)$ \\
중심섬향수준 & 높은 수준 & $2.99(50)$ & $3.92(53)$ \\
\hline 각 조건에서의 설독흐과 평균치 ()$^{2}$ & 각 센의 & 빈도
\end{tabular}

a: 각 조건에서의 설독효과 평균치, ()는 각 셀의 빈도

<표 9> 소비자의 자기지역중심성향수준 집단별 지역정서소구메시지 유형들의

설득효과 차이분석

\begin{tabular}{|c|c|c|c|c|c|c|}
\hline & 수준구분요인 & $\begin{array}{c}\text { 자숭합 } \\
\text { (SS) }\end{array}$ & $\begin{array}{c}\mathrm{df}^{*} \\
(\mathrm{n} 1=97) \\
(\mathrm{n} 2=103)\end{array}$ & $\begin{array}{c}\text { 평균자숭 } \\
\text { (MS) }\end{array}$ & $\mathrm{F}$ 값 & $P$ 값 $^{b}$ \\
\hline \multirow{3}{*}{$\begin{array}{l}\text { 낮 } \\
\text { 은 } \\
\text { 수 } \\
\text { 준 }\end{array}$} & 집단간 분산 & 50.649 & 1 & 50.649 & 25.062 & $.000^{* * *}$ \\
\hline & 집단내 분산 & 191.989 & 95 & 2.021 & & \\
\hline & 합계 & 242.638 & 96 & & & \\
\hline \multirow{3}{*}{$\begin{array}{l}\text { 높 } \\
\text { 은 } \\
\text { 수 } \\
\text { 준 }\end{array}$} & 집단간 분산 & 22.287 & 1 & 22.287 & 8.498 & $.004^{* * *}$ \\
\hline & 집단내 분산 & 264.885 & 101 & 2.623 & & \\
\hline & 합계 & 287.172 & 102 & & & \\
\hline
\end{tabular}

a: $\mathrm{nl}=$ 낮은 자기지역충심성향 집단, $\mathrm{n} 2=$ 높온 자기지역중심성향 집단

$b: * * * 0.01$ 
<그립 2> 소비자의 자기지역중심성향수준과 지역정서소구

메시지 유형별 설득효과

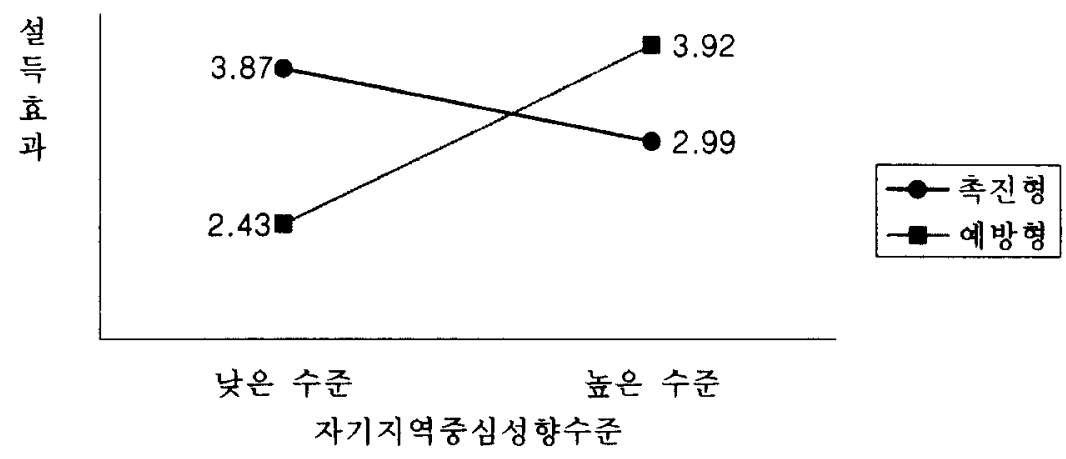

<표 9>, <그립 2>의 분석결과 소비자의 자기지역중심성향수준이 낮은 집단에서는 예방형 메시지(mean=2.43)보다 촉진형 메시지 $(m e a n=3.87)$ 가 더 설득적 효과가 있었고, 반대로 자기지역중심성향수준이 높은 집단에서는 촉진형 메시지(mean=2.99) 보다는 예방형 메시지 $(\mathrm{mean}=3.92)$ 의 설득효과가 더 큼을 알 수 있었다(p<.01). 이는 가설 1에서 검토한 바와 마찬가지로 비록 동일한 지역정서소구광고라 할지라도 메시지의 형태와 소비자의 자기지역중심성향수준에 따라 광고에 대한 설득효과가 달라질 수 있음을 의미한다. 즉, 자기지역중심성향수준이 낮은 소비자들은 지역정서소구광고에 노출되었을 때 지역정서소구 단서들에 따론 감정적 반웅들이 상표평가에 이용될 가능성이 매우 적기 때문에, 이에 따라 상표평가가 보다 제품과 직접 관련된 중심적 단서들을 바탕으로 이루어지기가 윕다. 따라서 이때에는 지역연고 제품으로서 제품자체의 장점들을 부각시키는 촉진형 광고메시지가 더 설득적임을 시사하고 있다.

반대로, 소비자의 자기지역중심성향수준이 높은 집단의 경우에는 상표자체에 대한 속성정보나 기능적 우수성들의 메시지보다도 지역민으로서 책임감 등을 강조하는 지역정서소구메시지들에 더 큰 영향을 받는 것으로 나타났다. 따라서 이들에게는 실제 지역민으로서 바람직한 행동들을 이행하지 않음으로써 초래되는 부정적 결과들을 부각시키는 예방형 메시지가 촉진형 메시지보다 상대적으로 더 설득적임을 시사해주고 있다. 결과적으로 가설 2 도 지지됨을 확인하였다

\section{5. 연구의 시사점 및 미래 연구방향}

본 연구는 최근 기업들이 광고촉진의 한 수단으로서 수행하고 있는 지역정서소구광고의 메시지효과를 소비자의 지식수준과 자기지역중심성향의 조절적 역할 관점에서 검토하였다. 이를 위하여 본 연구에서는 먼저 지역정서소구메시지의 유형올 제품들의 기능이나 우수성 등을 부각시키는 촉진형 데시지와 지역민으로서의 책임감이나 의무감 등에 호소하는 예방형 
메시지로 분류하고, 이들간에 지역소비자에 대한 메시지의 설득효과가 소비자의 지식수준과 자기지역중심성향수준에 따라 차이가 있는지를 탐색적으로 살펴 보았다. 그 결과 소비자의 개인특성으로서 제품에 대한 지식수준과 자기지역중심성향수준을 고려했을 경우에 촉진형 메시지와 예방형 메시지에 대한 설득효과는 다름을 알 수 있었는데, 지식수준이 높온 집단에서는 촉진형 메시지가 더 설득적이었고, 지식수준이 낮은 집단에서는 예방형 메시지가 더 설득적임을 발견하였다. 반면에 소비자의 자기지역중심성향수준에 따라서는, 낮은 수준의 집단에서는 촉진형 메시지가, 높은 수준의 집단에서는 예방형 메시지가 더 설득적인 것으로 나타났다.

이와 같은 결과를 토대로 본 연구는 다음과 같은 관리적 시사점들을 제시할 수 있다.

오늘날 범람하는 수많은 광고들 속에는 다양한 형태의 광고소구들이 존재하는데, 특히 감성적 광고의 중요성이 많이 부각되고 있다(김완석 1993, 1995; 이학식 1991; Batra and Ray 1986; Holbrook and Batra 1987; Stayman and Aaker 1988). 본 연구는 감성적 소구의 한 형태로서 최근 많이 실행되고 있는 지역정서소구에 대한 광고의 설득효과를 검토하여 보았다. 그 결과 소비자읙 개인특성을 고려했을 경우 각 메시지유형의 설득효과가 차이가 있음을 발견하였다. 이는 소비자 개인 특성에 따라 지역정서소구내용들이 소비자에게 긍정 또는 부정적 감정들을 유발시킴으로써 상표태도나 구매의도에 영향을 미칠 수 있음을 시사해 주고 있다. 따라서 지역정서소구 광고를 하려는 소매점포나 지역 기업들의 경우 이를 보다 효과적으로 활용하여 지역 소비자들을 유인할 수 있는 광고전략들의 필요성이 제기된다. 이러한 점은 최근 날로 증가하고 있는 지방화시대의 지방분뤈화 움직임의 가속화와 더불어 지역상권을 공략하려는 마케터들에게 보다 적극적으로 지역정서를 주제로 한 특정 감정소구 기법들의 필요성을 제안하고 있으며, 마케터들에게 광고설계전략과 관련된 시사점들을 본 연구결과가 제시해 주고 있다고 할 수 있다.

지역정서소구광고들은 어떠한 형태로 설계하는 것이 효과적일까? 본 연구는 지역정서소구 광고의 메시지유형별 설득효과에 있어서 소비자의 지식수준별로 어떻게 다른가를 살펴본 결과 지식수준이 낮은 집단의 경우 제품의 우수성 둥을 부각시키는 촉진형 광고메시지 보다는 지역민으로서의 책임감이나 도덕적 의무감 등에 소구하는 예방형 메시지가 더 설득적인 것으로 나타났다. 즉, 지식수준이 낮은 집단의 소비자들에게는 부정적 결과의 초래를 미연에 방지하도록 하는 예방형 메시지를 통해 상표태도나 구매의도가 형성되기 섭다. 이는 지식수준이 낮은 소비자들이 광고에서 제시되는 인지적 메시지들을 통해 상표를 평가할 능력들이 부족하기 때문에 상표평가에 대한 확신성이 부족하고, 더 나아가 이러한 불확신성은 다른 정보 또는 타인 의존적 행위를 더 쉅게 유도할 수 있음을 의미한다. 이러한 결과는 자기규제목표(self-regulatory goals)의 설득효과에 대한 영향력을 고찰한 Aaker and Lee(2001)의 연구결과와도 일치함을 보여주고 있다.

반면, 지식수준이 높은 소비자집단에서는 예방형 지역정서소구광고메시지보다 촉진형 지역정서소구광고메시지가 더 설득적인 것으로 나타났다. 이는 이러한 집단에게는 비록 지역정서소구광고라 할지라도 제품과 직접 관련되어 있는 기능적 우수성이나 또는 여러 가지 장점들을 어필하는 메시지가 제품과 직접 관련이 없는 예방적 차원의 메시지보다 더 효과적임을 의미한다. 그 이유는 지식수준이 높은 소비자들은 노출된 광고물 속에 포함되어 있는 제품정보에 대하여 활발한 인지반웅올 할 수 있고, 이에 따라 이 과정을 통한 자기판단의 확신성이 매우 높다고 할 수 있다. 즉, 자율적인 판단 또는 의사결정에 따른 성취감과 다른 사람들과 비교하여 더 나은 목표를 성취하려는 열정 둥이 크다고 할 수 있다. 
Aaker and Lee(2001)는 이러한 유형의 소비자들에게는 설득정보의 제공시 예방형(즉, 위험회피형) 메시지보다는 촉진형 메시지가 더 설득적임을 주장하고 있는데, 본 연구결과도 이를 뒷받침해주고 있다고 할 수 있다.

한편, 본 연구에서는 소비자의 지식수준과 더불어 소비자의 자기지역중심성향에 따라서도 지역정서소구메지시의 유형별 영향력이 달라짐을 확인하였는데, 자기지역중심성향이 낮은 집단의 경우에는 촉진형 메시지가 더 설득적이었고, 자기지역중심성향이 높은 소비자들 에게는 예방형 메시지가 더 설득적인 것으로 나타났다. 즉, 자기지역중심성향이 높은 소비자들에게는 호의적인 상표태도나 구매의도를 높이기 위해 지역제품을 사용하지 않음으로 해서 지역산업의 퇴조나 실업중가와 같은 논리적 근거를 메지시 내용으로 하는 예방형 광고가 효과적이고, 자기지역중심성향이 낮은 소비자들의 경우에는 호의적인 상표태도를 위해 제품자체의 우수성 등을 강조하는 촉진형 광고가 더 설독적임을 알 수 있었다.

소비자의 자기지역중심성향과 유사한 맥락으로서 소비자들의 자민족중심주의를 고찰한 선행연구들을 보면(이동대 \& 신창훈 2001; Netemeyer, Durvasula and Lichtenstein 1991; Shimp and Sharma 1987), 소비자들의 자민족중심주의는 자국 또는 타국점포에 대한 태도나 상표태도 둥에 영향을 미친다고 제안하고 있다. 특히 자민족중심주의 경향이 강한 소비자들의 경우 자국 점포나 상표에 대해 더 호의적인 반응을 보이고, 타국 점포나 상표에 대해 더 부정적인 태도를 보이는 것으로 알려지고 있다. 이와 같은 맥락에서 본 연구에서 제안한 소비자의 자기지역중심성향도 지역내 점포나 제품태도에 영향을 미칠 것으로 기대되었다. 즉, 자기지역중심성향이 강한 소비자들은 자기지역 제품에 대해서 더 호의적인 반응을 보이고, 타지역 제품들에 대해서는 상대적으로 비호의적 태도를 형성하기가 쉅다. 따라서 지역 마케터들은 소비자들의 자기지역중심성향을 자극하거나 강화함으로써 타지역 제품들에 비해 더 좋은 제품태도를 형성할 수 있고, 반대로 타지역의 마케터들에게는 자사제품들이 특정 지역시장에 더 쉅게 진입하기 위하여 소비자들의 자기지역중심성향수준 을 약화시키거나 또는 회석시킬 수 있는 설득전략들이 요구된다고 할 수 있다. 이때 본 연구결과에 의하면 자기지역중심성향이 강한 소비자들에게는 예방형 메시지를 통해 지역제품에 대한 태도를 더 극대화시킬 수 있고, 반대로 특정 시장을 공략하려는 타지역 제품들의 경우 제품자체의 우수성 등을 강조하는 촉진형 메시지를 통해 타지역 제품에 대한 비호의적인 태도를 희석시키거나 약화시킬 수 있다. 따라서 이러한 점들은 실무 기업촉면에서 기업이 설득광고소구를 소비자에게 전달하고자 할 경우 광고되는 제품에 대하여 소비자의 개인적 특성에 따라 차별적인 광고전략올 어떻게 수립해야 하며, 광고메시지를 어뗳게 설계하는 것이 소비자들을 보다 잘 설득할 수 있는가에 대한 하나의 지침을 제공해준다고 할 수 있다.

그러나 본 연구는 이러한 시사점에도 불구하고 다음과 같은 일부 한계점들이 있으며, 추후 이를 보완할 수 있는 보다 심충적인 연구가 뒷받침되어야 할 것으로 판단된다.

먼저, 본 연구는 실험대상 제품의 선정에 있어서 비교적 피실험자들이 많은 관심을 가지고 있는 제품이면서도 지식수준의 측정이 용이하다고 판단되는 컴퓨터를 가지고 수행하였다. 그러나 실헙대상제품을 하나의 제품군으로 한정함으로써 이로 인하여 보다 다양한 제품군에서의 지역정서소구 광고효과의 검토가 충분히 이루어지지 못했다는 한계점이 있다. 따라서 제품선정시 보다 폭넓은 제품군의 고려를 통해 지역정서소구의 광고효과를 검토해 볼 필요가 있다. 왜나하면 일반적으로 경쟁상표와 제품특성의 차이가 
별로 없거나 또는 소비자에게 긍정적인 감정을 유발할 수 있으면서도 감정경험과 행동사이에 시간적 격차가 적은 제품일 수록 감정광고가 효과적인 것으로 알려지고 있기 때문이다. 예를 들어 의류나 음료 또는 식품분야처럼 경쟁상표가 매우 많고, 각 상표의 품질수준이 별 차이가 없거나 소비자의 품질지각이 매우 주관적인 분야의 제품들에서 특히 지역정서소구와 같은 특정 감정에 소구하는 광고가 더 효과적일 것으로 예상된다. 그러므로 향후 연구에서는 보다 다양한 제품카테고리별 접근이 요구되며 이를 통해서 각 제품유형별로 지역정서소구광고의 효과를 제시하는 것도 니치마켓(niche market)을 지향하는 지역 마케터들에게 더 큰 의미를 부여해 줄 것으로 기대할 수 있다.

또한 본 연구는 지역정서소구광고의 효과적인 설계전략들을 탐색하기 위하여 지역정서 소구메시지 유형들을 지역에서 생산된 제품으로서 제품의 우수성 둥을 강조하는 촉진형 광고와 지역민으로서 지역경제와 산업을 살리기 위해 지역상품을 구매해 주어야 한다는 당위성 둥을 부여해주는 예방형 광고로 분류하여 살펴보았다. 이와 같은 메시지의 분류는 지역정서소구광고 못지않게 보다 더 범위를 확장하여 소비자의 애국심이나 자민족 정서에 소구하는 광고의 연구들에도 유용하게 적용시킬 수 있을 것으로 판단된다.

아울러 본 연구에서는 지역정서소구광고의 설득효과를 살펴보는데 있어서 소비자의 개인특성 변수로서 지식수준과 자기지역중심성향수준별로 그 차이가 어떠한지를 살펴보았다. 그러나 이러한 조절변수의 개별적 차이와 더불어 지식수준과 자기지역중심성향수준간의 상호작용효과도 검토해 볼 필요가 있다. 그리고 이를 위해서는 먼저 소비자의 제품에 대한 지식과 소비자가 가지고 있는 제품과 관련된 지역정서의 두 효과가 상대적으로 어떻게 영향을 미칠 것인가에 대한 관련이론들의 정립 및 실증적 연구가 수행될 필요가 있다. 예를 들어, 지식수준이 높고 자기지역중심성향 수준이 높은 소비자들의 경우 촉진형 메시지가 더 상승효과를 보일 것인지 또는 지식수준이 낮고 자기지역중심성향 수준도 낮은 경우 예방형메시지가 더 상승효과를 보일 것인지, 아니면 이들간에 별다른 차이가 없을 것인지 둥에 대한 이론적, 실증적 연구가 향후 보다 정교한 실험설계를 통하여 뒷받침 되어야 할 것으로 판단된다.

끝으로, 본 연구에서는 지역정서소구가 반영된 광고효과에 대하여 소비자 개인특성변수 중 정보처리능력변수로서 제품의 지식수준을 고려하여 검토하였다. 그러나 광고효과에 대해 ELM에 따르면 정보처리능력 못지 않게 정보처리동기도 매우 중요한 요소로서 검토되고 있다(박찬욱 2001). 그리고 이러한 정보처리동기는 정보처리능력수준과 관련하여 광고효과에 대해 서로 상이한 영향력을 가질 수 있다. 따라서 향후 연구에서는 정보처리능력과 정보처리동기를 함께 고려한 지역정서소구광고의 효과검토도 고려해 볼 필요가 있다. 


\section{<참고문헌>}

김완석 (1991), “광고가 유발한 감정과 광고효과," 광고연구, 여름호, 91-112.

김완석 (1993), “소비자의 감정적 반응과 광고효과 과정: 유형별 차이와 개인차," 광고연구,

겨울호, 31-70.

김완석 (1995), “특정 감정에 소구하는 광고의 효과기재," 광고연구, 가을호, 9-34.

김혜란, 송인덕 (1998), “애국심강도와 광고메시지 유형에 따른 애국심호소광고의 효과연구," 광고연구, 겨울호, 169-192.

박찬욱 (2001), “제품지식이 적은 소비자의 원산지 정보 및 광고모델 정보 활옹전략:

정보처리 동기와 제품유형의 조절적 역할을 중심으로," 마케팅연구, 16(2), 49-68.

서범석 (1993), 「광고기획론」, 나남.

안광호·유창조 (1998), 「광고원론」, 법문사.

이동대, 신창훈 (2001), “소비자들의 소매점 태도 형성에서의 자민족중심주의의 역할,"

소비자학연구, 12(1), 1-16.

이두희 $(2000)$, 「광고론」, 박영사.

이학식 (1991), “정서적 반웅이 광고효과에 미치는 영향: 제품소비경험과 관여도의 조정적

역할," 경영학연구, 21(1), 345-367.

이학식, 김종성 (1999), “상표확장효과의 조절변수로서 소비자 특성과 지각의 역할평가," 마케팅연구, 14(2), 23-44.

이학식, 정주혼, 이호배 (1998), "광고효과의 조절변수로서 인지욕구과 감성강도의 평가,"

마케텅연구, 13(1), 105-131.

임종원 (1996), 「마케텅조사 이렇게」, 법문사.

정해진 (1996), "애국심호소광고의 효과 차이에 관한 연구," 부산여대 석사학위논문.

최명규 (1994), “제품평가에 있어서의 제조국 효과에 영향을 미치는 변수에 관한 연구:

제품-제조국 이미지 일치, 소비자 자기민족중심주의, 제품관여도를 중심으로,"

소비자학연구, 5(2), 17-32.

한충민 (1998), "대의명분마케팅-애국심 전략," 광고정보, 36-40.

Aaker, Jennifer L. and Angela Y. Lee (2001), "I" Seek Pleasures and "We" Avoid Pains: The Role of Self-Regulatory Goals in Information Processing and Persuasion," Journal of Consumer Research, 28, 33-49.

Alba, Joseph W. and J. Wesley Hutchinson (1987), "Dimensions of Consumer Expertise," Journal of Consumer Research, 13(March), 411-454.

Andrews, J. Craig (1988), "Motivation, Ability, and Opportunity to Process Information: Conceptual and Experimental Manipulation Issues," Advances in Consumer Research, 15, 219-225.

Batta, R. and M. L. Ray (1986), "Affective Responses Mediating Acceptance of Advertising," Journal of Consumer Research, 13(September), 234-249.

Brucks, Merrie (1985), "The Effects of Product Class Knowledge on Information Search Behavior," Journal of Consumer Research, 12(June), 1-16.

Brucks, Merrie (1986), "A Typology of Consumer Knowledge Content," in Advances in Consumer Research, 13, ed. Richard J. Lutz, Provo, UT: Association for Consumer Research, 58-63

Burke, M. C. and J. A. Edell (1989), "The Impact of Feelings on Ad-based Affect and Cognition," Journal of Marketing Research, 26(February), 69-83. 
Celsi, Richard L. and Jerry C. Olson (1988), "The Role of Involvement in Attention and Comprehension Processes," Journal of Consumer Research, 15(September), 210-224.

Duncan, Calvin P. and Richard W. Olshavsky (1982), "External Search: The Role of Consumer Beliefs," Journal of Marketing Research, 19(February), 32-43.

Fishbein, M. and Icek Ajzen (1975), Belief, Attitude, Intention and Behavior, Reading, MA: Addison-Wesley Publishing Company.

Friestad, M. and E. Thorson (1986), "The Effects of Emotion on Recall and Evaluation of Televised Promotional Messages," Unpublished Manuscript, Madison: University of Wisconsin.

Greenwald, A. G. (1968), "Cognitive Learning, Cognitive Response to Persuasion and Attitude Change," in A. G. Greenwald, T. B. Brock and T. M. Ostrom(Eds.), Psychological Foundations of Attitudes, N.Y. Academic Press.

Higgins, E. Tory (1997), "Beyond Pleasure and Pain," American Psychologist, 52(December), 1280-1300.

Holbrook, M. B. and Batra, R. (1987), "Assessing the Role of Emotion as Mediators of Consumer Response to Advertising," Journal of Consumer Research, 14, 404-420

Johnson, E. and J. E. Russo (1984), "Product Familiarity and Learning New Information," Journal of Consumer Research, 11(June), 542-550.

Klein, Jill Gabrielle, Richard Ettenson and Marlene D. Morris (1998), "The Animosity Model of Foreign Product Purchase: An Empirical Test in the People's Republic of China," Journal of Marketing, 62(January), 89-100.

Levine, Robert A. and Donald T. Campbell (1972), "Ethnocentrism: Theories of Conflict, Ethnic Attitudes, and Group Behavior," NY: John Wiley.

Netemeyer, Richard G., Durvasula S. and D. R. Lichtenstein (1991), "A Cross-National Assessment of the Reliability and Validity of the CETSCALE," Journal of Marketing Research, 28(3), 320-327.

Nunnally (1978), Psychometric Theory, New York: McGraw-Hill Book Company.

Park, C. Whan and V. P. Lessig (1981), "Familiarity and its Impacts on Consumer Decision Biases and Heuristics," Journal of Consumer Research, 8(September), 223-230.

Park, C. Whan, David L. Mothersbaugh and Lawrence Feick (1994), "Consumer Knowledge Assessment," Journal of Consumer Research, 21(June), 7 i-82

Petty, Richard E., John T. Cacioppo (1979), "Issue Involvement Can Increase or Decrease Persuasion by Enhancing Message-relevant Cognitive Responses," Journal of Personality and Social Psychology, 37(10), 1915-1926.

Petty, Richard E., John T. Cacioppo (1981), "Issue Involvement as Moderator of the Effects on Attitude of Advertising Content and Context," in Advances in Consumer Research, 8, Ed. Kent B. Monroe, Ann Arbor, MI: Association for Consumer Research, 20-24.

Petty, Richard E., John T. Cacioppo (1986a), Communication and Persuasion: Central and Peripheral Routes to Attitude Change, New York: Springer-Verlag.

Petty, Richard E., John T. Cacioppo, and David Schumann (1983), "Central and Peripheral Routes to Advertising Effectiveness: The Moderating Role of Involvement," Journal of Consumer Research, 10(September), 135-146.

Rao, Akshay R. and Kent B. Monroe (1988), "The Moderating Effect of Prior Knowledge on Cue Utilization in Product Evaluations," Journal of Consumer Research, 15 (September), 253-264.

Rao, Akshay R. and Wanda A. Sieben (1992), "The Effect of Prior Knowledge on Price Acceptability and the Type of Information Examined," Journal of Consumer Research, 19(September), 256-270

Shimp, T. A. (1981), "Attitude toward the Ad as a Mediator of Consumer Brand Choice," Journal of 
Advertising, 10, 9-15.

Shimp, T. and S. Sharma (1987), "Consumer Ethnocentrism: Construction and Validation of the CETSCALE," Journal of Marketing Research, 24(August), 280-289.

Stayman, D. M. and Aaker, D. A.(1988), "Are all the Effects of Ad-induced Feelings Mediated by Ad?," Journal of Consumer Research, 15, 368-373.

Sujan M. (1985), "Consumer Knowledge: Effects on Evaluation Strategies Mediating Consumer Judgments," Journal of Consumer Research, 12(June), 31-46.

Zajonc, Robert B. (1968), "The Attitudinal Effect of Mere Exposure," Journal of Personality and Social Psychology Monograph, 9, 1-27.

Zinkhan, G. M. and A. Muderrisoglu (1985), "Involvement, Familiarity, Cognitive Differentiation, and Advertising Recall: A Test of Convergent and Discriminant Validity," In: E.C. Hirschman and M Holbrook (eds.), Advances in Consumer Research, 12, 356-361, Provo, UT: Association for Consumer Research. 


\section{<부 록>}

\section{1. 광고효과의 측정문항}

1) 지역정서 소구 정도(local emotion appeal)

LE1. 이 광고는 나에게 지역정서를 느끼게 한다.

LE2. 이 광고는 나에게 애향심을 느끼게 한다.

LE3. 이 광고메시지는 지역적 색채를 많이 강조하고 있다.

LE4. 다른 사람들이 만약 이 광고를 본다면 그들도 애향심을 떠올릴 것이다.

2) 촉진형 메시지의 소구 정도(promotion message)

PM1. 이 광고메시지는 제품들의 장점을 강조해 주고 있는 것 같다.

PM2, 이 광고메시지는 제품의 우수성올 강조하고 있는 것 같다.

PM3. 이 광고메시지는 제품에 대한 자부심을 강조하고 있다.

PM4. 이 광고에서 제시된 제품은 실용성 있는 제품이라고 생각한다.

PM5. 이 광고메시지는 유니컴이 좋은 제품이라는 것을 강조하고 있는 것 같다.

3) 예방형 메시지의 소구 정도(prevention message)

$\mathrm{PV} 1$. 이 광고메시지는 지역민으로서의 책임감을 느끼게 한다.

PV2. 이 광고메시지는 지역민으로서의 도덕적 의무감을 느끼게 한다.

PV3, 이 광고메시지는 지역민의 무관심이 지역경제의 낙후를 초래할 수 있음을 강조하고 있다.

$\mathrm{PV} 4$. 이 광고메시지는 자기지역제품을 구매할 것을 설득하는 것 같다.

PV5. 이 광고메시지는 유니컴 PC를 구입하면 지역발전에 기여할 수 있음을 강조하고 있다.

4) 설득효과(persuasion effects)

PE1. 이 광고메시지는 내가 유니컴올 구매하고자 할 때 매우 효과적인 정보라고 생각한다.

$\mathrm{PE} 2$. 나는 평소 위와 같은 광고메시지들올 선호하는 편이다.

PE3. 이 광고메시지는 내가 유니컴을 평가하는데 매우 효과적인 정보라고 생각한다.

$\mathrm{PE}$. 내가 만약 유니컴을 구매하게 된다면 위와 같은 광고메시지들은 나의 구매의사결정에 좋은 참고가 될 것이다.

PE5, 이 광고메시지를 읽고 나는 유니컴을 구매하고 싶다는 생각이 들었다.

$\mathrm{PE}$. 나는 위와 같은 광고메시지들에 호감이 간다.

$\mathrm{PE}$ 7. 만약 구매를 고려할 때 위와 같은 광고메시지들이 나에게 제시된다면 내 판단에 적극적으로 활용하고 싶다.

주) 7점의 등간 척도임(전혀 그맇지 않다/매우 그렇다)

\section{2. 소비자 지식의 측정문항}

1) 객관적 지식(object ive knowledge)

OK1. 나는 컴퓨터를 구매한 적이 있다.(1)

OK2. 나는 현재 컴퓨터를 가지고 있다. (1) 
OK3. 나는 컴퓨터를 사용해본 경험이 있다.(1)

OK4. 나는 컴퓨터를 구매하기 전에 여러 종류의 컴퓨터를 비교해 본다. (1)

OK5. 나는 개인용 컴퓨터의 중간 가격 범위가 400 만원에서 500 만원 사이일 것으로 생각한다. (2)

0K6. 트랙(Track)은 디스크의 기억 표면이 동심원으로 나누어진 상태를 말한다. (1)

OK7. 컴퓨터 범죄를 예방하기 위해서는 한 번 설정한 패스워드는 가급적 변경하지 않는다. (2)

0K8. 대표적인 절차지향형 언어로는 $\mathrm{COBOL}, \mathrm{FORTRAN}$ 이 있다.(1)

OK9. 운영체제(OS), 어셈블러(assembler), 엑셀 (exce1) 등은 시스템 소프트웨어이다.(2)

OK10. Windows 탐색기에서 연속되지 않은 여러 개의 파일을 선택하고자 한다면 Alt 상태에서 파일이나 폴더를 클릭하면 된다.(2)

OK11. 2 Modem은 PC통심망에서 많이 사용되고 있는 모뎀 프로토콜(protocol)이다. (1)

0K12. 1 기가바이트(GB)는 1024 킬로바이트(KB)이다. (2)

$0 \mathrm{k} 13$. Rom은 데이터를 앍고 쓸 수 있으며, 전원공급이 중단되면 데이터가 지워진다. (2)

OK14. Windows가 하드디스크 공간을 예약하여 추가 메모리로 사용하도록 지정할 수 있는 장치를 가상 기억장치(virtual memory)라 한다.(1)

OK15. 산술논리 연산장치와 제어장치는 중앙처리장치의 구성요소이다. (1)

주) ( )은 정답임, [ 예(1), 아니오(2), 모르겠다(3) ]

2) 주관적 지식(subject knowledge)

SK1. 나는 컴퓨터를 잘 알고 있다고 생각한다.

$\mathrm{SK} 2$. 나는 나의 동료에 비해 컴퓨터를 잘 알고 있는 편이다.

SK3. 나는 컴퓨터에 매우 친숙하다고 생각한다.

주) 7 점의 둥간 척도임(전혀 그렇지 않다/매우 그렇다)

\section{3. 소비자의 자기지역중심성향(CLOCAL: consumer localism)의 측정문항}

CL1. 가급적 내가 원하는 제품이 0 지역에서 생산할 수 없올 때에만 다른 지역의 제품을 구매해 주어야 한다.

$\mathrm{CL} 2$. 진정한 00 인은 가급적 이 지역에서 만든 것을 구매해 주어야 한다.

CL3. 동일한 조건이라면 타 지역 제품을 구매하는 것은 00 인의 도리가 아니다.

CL4. 00 인은 항상 00 지역애서 생산된 제품을 구매해 주어야 한다.

CL5. 00 인이 00 지역에서 생산된 제품올 구매하지 않는 것은 이 지역 기업을 해치는 행위라고 생각한다.

CL6. 00지역에서 생산한 제품을 구매하는 것이 지역기업을 살리는 길이다.

CL7. 나는 이 지역에서 생산된 제품을 타 지역에서 생산된 제품보다 더 신뢰한다.

CL8. 00 에서 생산된 제품들의 품질은 항상 좋다.

CL9. 나는 이 지역에서 생산된 제품을 다른 지역에서 생산된 제품보다 더 좋아한다.

CL10, 나는 가격이 같다면 다른 지역제품보다 이 지역에서 생산된 제품올 구매하겠다.

주) 7점의 둥간 척도임(전혀 그렇지 않다/매우 그렇다) 